\title{
4
}

\section{The Autopsy Pathology of Sepsis-Related Death}

\author{
Sebastian Lucas \\ Dept of Histopathology \\ KCL School of Medicine \\ St Thomas' Hospital \\ London \\ UK
}

\section{Introduction}

Sepsis is defined as infection plus systemic manifestations of infection (Dellinger.R.P. et al. 2008). Thus it is more than just the local organ pathology damage, and indicates malfunction of one or more other critical organs. There are few systematic reviews of what autopsy can contribute to sepsis studies, so this chapter attempts to summarise the main pathological concepts around sepsis with particular focus on diagnostic features - gross and histopathological - and differential diagnosis. The focus is information for practising pathologists. Currently, detailed non-forensic autopsy practice seems to have fewer enthusiasts than heretofore, and the case is made that in sepsis-related fatality, there is much to observe and learn. This chapter is a revision of an article on the autopsy and sepsis published in 2007 (Lucas 2007).

Autopsy pathologists not infrequently use the term 'septicaemia' (implying blood infection) as the final process causing death, implying that there was bacteraemia - hopefully proven but sometimes assumed - associated with one or more organ failures. This is an uneasy combination of clinical, laboratory and gross pathological features, because:

1. there are no specific morbid anatomical features of 'septicaemia'

- the historical 'diffluent' or 'septic' spleen is a debatable gross entity (ArismendiMorrillo et al. 2004)

- 'shock lung' and 'acute tubular necrosis' are difficult to diagnose on gross examination alone

2. the interpretation of pre-mortem, let alone post-mortem, blood cultures is not easy (Morris, Harrison, \& Partridge 2006)

3. there are no standard histopathological features that reliably point to 'septicaemia'

4. there is no agreed case definition of 'septicaemia'.

It is more logical to consider 'sepsis': its local origins, systemic consequences, and degrees of severity.

Within intensive care units (ICU), where most patients with severe sepsis are cared for (Dellinger et al. 2004), autopsy analysis still reveals previously unknown diagnoses that could, if treated differently, have altered the outcome; and this despite the panoply of investigative procedures now available to modern ICU medicine. From the $21^{\text {st }}$ century, a USA study (Roosen et al. 2000) found 16\% Goldman class 1 discrepancies (ie missed 
opportunity to change therapy and prolong survival (Goldman et al. 1983)), and fungal infections were notably under-diagnosed pre-mortem. In a recent French study (Combes et al. 2004) $32 \%$ of autopsies showed Goldman class 1 or 2 discrepancies, particularly among the immuno-compromised patients. The diseases missed included cancer, stroke, myocardial infarction, endocarditis, and pulmonary embolism. A British study (Perkins et al. 2003) noted that only $7.7 \%$ of ICU deaths underwent autopsy, and found similar discrepancy patterns to the French study. What few of these studies address is the precise contribution of sepsis and its management to death, although severe sepsis is noted to be both under- and over-diagnosed pre-mortem (Blosser, Zimmerman, \& Stauffer 1998) (Perkins, McAuley, Davies, \& Gao 2003).

\subsection{The role of the autopsy in sepsis}

What can autopsy pathology - and pre-mortem cellular pathology - contribute to improving the care and outcomes of sepsis patients? There are three main categories of positive contribution:

1. assisting in diagnosis pre-mortem, through tissue examination (histopathology and cytopathology (Schnadig, Molina, \& Aronson 2007))

2. evaluating dead patients for actual clinico-pathological outcomes

- confirming or refuting pre-mortem diagnoses

- including potential complications of intensive care

- identifying co-morbidities that affected recovery

3. providing this information back to clinicians and IC units as monitoring and audit in order to feed into improving future managements

The 2008 revision of the clinical Recommendations for Surviving Sepsis Campaign (Dellinger.R.P., Levy, Carlet, \& et al 2008) can be scrutinized against possible contributions of pathology. For several of the Recommendations, autopsy pathology investigations can contribute nothing specifically:

1. Initial Resuscitation

2. Glucose Control

3. Renal Replacement

4. Bicarbonate Therapy

5. Selective Digestive Tract Decontamination

6. Consideration of Limitation of Support

But for the other Recommendations, autopsy pathology can contribute significantly to the evaluation in their efficacy and complications:

1. Diagnosis - of infections and co-morbidities

2. Antibiotic Therapy - effectiveness of therapy, and potential toxic complications of therapy

3. Source Control - as with Diagnosis of infections

4. Fluid Therapy - overload, underperfusion

5. Vasopressors \& Inotrope Therapies - complications such as cardio-toxicity

6. Corticosteroids - complications including opportunistic infections6

7. Recombinant Activated Protein C - haemorrhagic complications

8. Blood Product Administration - identification of Transfusion Associated Lung Injury (TRALI)

9. Mechanical Ventilation of acute lung injury - the impact of tidal volume and $\mathrm{O} 2$ concentration on alveolar membranes 
10. Extracorporeal Membrane Oxygenation (ECMO) - its contribution to lung pathology (eg aspergillosis)

11. Sedation - the issue of possible morphine toxicity

12. Deep Vein Thrombosis Prophylaxis - its efficacy

13. Gastric Stress Prophylaxis - its efficacy

\section{Epidemiology}

Epidemiologically, the incidence of severe sepsis (as defined below) in industrialised countries is $50-95$ cases per 100,000 population and is rising by up to $9 \%$ each year, for reasons still unexplained. It accounts for $2 \%$ of hospital admissions in the USA, affecting about 700,000 people per year, causing death in 210,000; and is the tenth leading cause of death (Annane, Bellisant, \& Cavaillon 2005) (Riederman, Guo, \& Ward 2003) (Danai \& Martin 2005) (Lever \& Mackenzie 2007).

\section{Clinical case definitions}

As a result of consensus meetings in the early 1990s- intended to improve not only patient management but also the comparability of clinical trials in intensive care unit settings (ICU) - there are agreed clinical case definitions of sepsis, including severity and organ syndromes (see Table 1) (Riederman, Guo, \& Ward 2003) (Levy \& et al 1992). The recognition of the systemic inflammatory response syndrome (SIRS) is central to the definitions.

\begin{tabular}{|l|l|}
\hline Diagnosis & Definition \\
\hline SIRS (systemic inflammatory response & $\begin{array}{l}\text { Temperature }>38 \text { deg C or }<36 \text { deg C } \\
\text { Heart rate }>90 / \mathrm{min}\end{array}$ \\
& $\begin{array}{l}\text { Systolic blood pressure }<90 \mathrm{mmHg} \\
\text { Respiratory rate }>20 / \mathrm{min} \text { or PaCO2 } \\
<32 \mathrm{mmHg} \\
\text { Blood white cell count }>12 \times 10^{9} / \mathrm{L} \text { or } \\
<4 \times 10^{9} / \mathrm{L}, \text { or }>10 \% \text { immature band forms. }\end{array}$ \\
\hline Sepsis & $\begin{array}{l}\text { Systemic response to infection, as } \\
\text { manifested by two of more of the above list } \\
\text { (ie SIRS }+ \text { infection). }\end{array}$ \\
\hline Severe sepsis & $\begin{array}{l}\text { Sepsis with associated organ dysfunction, } \\
\text { hypoperfusion, or hypotension including } \\
\text { lactic acidosis, oliguria, or acute alteration } \\
\text { in mental state. }\end{array}$ \\
\hline Septic shock & $\begin{array}{l}\text { Sepsis-induced hypotension despite } \\
\text { adequate fluid resuscitation, along with } \\
\text { presence of severe sepsis. }\end{array}$ \\
\hline $\begin{array}{l}\text { MODS (Multiple organ dysfunction } \\
\text { syndrome) }\end{array}$ & $\begin{array}{l}\text { The presence of altered organ function in } \\
\text { an acutely ill patient such that homeostasis } \\
\text { cannot be maintained without intervention. }\end{array}$ \\
\hline
\end{tabular}

Table 1. Clinical definitions of sepsis

The six most common sites of infection associated with sepsis are pneumonia, blood stream infections (including infective endocarditis), intravascular catheter-related sepsis, intra- 
abdominal infections, urological sepsis, and surgical wound infections. Florid septic shock syndromes also arise post-delivery, from necrotising fasciitis, and menstrual toxic shock syndrome (see Table 2).

\begin{tabular}{|l|l|}
\hline Syndrome & Clinical features \\
\hline Meningococcal (Neisseria meningitidis) & Disseminated intravascular coagulation \\
bacteraemic shock & prominent \\
& Haemorrhagic rash (see Figs 2 \& 3) \\
& Mortality = 10-20\% \\
\hline $\begin{array}{l}\text { Staphylococcal (․aureus) } \text { toxic shock } \\
\text { syndrome }\end{array}$ & Menstrual (tampon-related) \\
& Non-menstrual \\
& Skin wounds, surgical wounds \\
& Pneumonia \\
& Catheter infections \\
& Mortality = 5\% \\
\hline Streptococcal (group A) toxic shock & Deep seated infections \\
syndrome & Necrotising fasciitis \\
& Surgical operation sites \\
& Puerperal sepsis \\
& Mortality = 50\% \\
\hline
\end{tabular}

Table 2. The three most severe fulminant and toxic shock syndromes (TSS) and some of their characteristics (Munford 2005) (Moreillon, Que, \& Glauser 2005) (Bisno \& Stevens 2005).

The staphylococcal and streptococcal TSS have a rapid onset because the bacteria secrete superantigens which directly activate T-cells, with release of much TNFa, and a rapid cytokine storm.

Further consensus meetings have arrived at agreed organ-specific case definitions, with emphasis on the stringency of the clinical characteristics and the microbiological investigations (Calandra, Cohen, \& et al 2005). Table 3 indicates that for pneumonia.

\section{Infections causing sepsis}

The spectrum of infections has changed. In the 1970-80s, gram-negative bacteria predominated. But in the $21^{\text {st }}$ century, the in-hospital case pattern is (Annane, Bellisant, \& Cavaillon 2005) (van der Poll.T \& Opal 2008):

- $25-30 \%$ gram-negative infections

- $30-50 \%$ gram-positive infections

- $25 \%$ polymicrobial infections

- $\quad 25 \%$ multi-drug resistant organisms (eg MRSA and fungi)

- $\quad 2-4 \%$ viral and parasitic infections (but probably underestimated) including malaria - $\quad$ eg HHV8/HIV co-infection (Fowler et al. 2006)

- $\quad 30 \%$ negative cultures: community-acquired sepsis treated with antibiotics before admission; and higher rates of negative cultures reported in neutropaenic sepsis.

- Mycobacterium tuberculosis, particularly when it is anergic pattern due to host immunosuppression (see Figs 12 \& 13). 


\begin{tabular}{|l|l|}
\hline Level of Certainty & Definition \\
\hline Microbiologically & $\begin{array}{l}\text { New or progressive radiological infiltrate } \\
\text { Confined (ie definite) } \\
\text { Pulmonary Infection Score (CPIS) =>6; this six-feature } \\
\text { scale includes identification of bacteria on gram stain } \\
\text { of lower respiratory tract samples. } \\
\text { Identification of a pathogen - one or more of the } \\
\text { following categories: } \\
\text { a. Uncontaminated sample (blood, pleural fluid, } \\
\text { transthoracic or transtracheal aspirate } \\
\text { b. Respiratory secretions, not a pathogen that colonises the } \\
\text { upper airways } \\
\text { a. A likely pathogen using quantitative cultures of } \\
\text { lower respiratory tract samples } \\
\text { b. Positive infection serology }\end{array}$ \\
\hline Probable & $\begin{array}{l}\text { Clinically as above, but the identification of a pathogen is } \\
\text { Below the diagnostic threshold, or } \\
\text { b. Negative within 72 hours of starting a new } \\
\text { antibiotic regime }\end{array}$ \\
\hline Possible & $\begin{array}{l}\text { Abnormal chest radiograph of uncertain cause in a patient } \\
\text { with moderate or low suspicion of pneumonia, but with } \\
\text { microbiological or serological evidence of definite or } \\
\text { probable pneumonia (as defined above). }\end{array}$ \\
\hline
\end{tabular}

Table 3. Pneumonia case definitions

The purpose of detailing these clinical case definitions is to contrast them with the morbid anatomical features of sepsis, which are less well depicted. Pathologists can assist clinical colleagues in evaluating patients dying of known or suspected sepsis, proving sepsis or identifying the differential diagnoses. They could thereby more usefully contribute to audit and the evaluation of novel therapies in sepsis.

\section{Pathogenesis of the sepsis syndromes}

SIRS is characterised as 'an abnormal generalised inflammatory reaction in organs remote from the initial insult' (Munford 2005). SIRS can result from non-infective causes, such as trauma, pancreatitis and cardiac-bypass procedures, and the pathologist needs to bear this in mind when evaluating deaths presented as '?sepsis'.

Enormous research has gone into identifying the pathogenesis of the remote organ damage that characterises severe sepsis; three recent reviews (Munford 2005) (Calandra, Cohen, \& et al 2005) (Annane, Bellisant, \& Cavaillon 2005) (van der Poll.T \& Opal 2008) (Lever \& Mackenzie 2007) emphasise how much we do not understand.

In brief, infections trigger a cytokine cascade via Toll-like receptors on inflammatory cells, with the excess secretion of many pro-inflammatory mediators including IL-1, TNFa, IL-6, nitric oxide (NO), platelet activating factor (PAF) (Mitchell 2005). Systemically, these affect organ function via damage to epithelia and endothelial cells (with abnormal microcirculation), inflammatory cell infiltration, initiation of the coagulation system, endocrine stimulation, and activation of the autonomic nervous system. The microbial 
triggers include endotoxin (lipopolysaccharide) in gram-negative bacilli and superantigens in gram-positive cocci. The cholinergic nervous system appears to be important in that it suppresses the production of pro-inflammatory cytokines (van der Poll.T \& Opal 2008).

Modern thinking is that in the early phase of SIRS, the response is balanced and with elimination of the infection, there can be full recovery. But if the response is unbalanced, with over-production of inflammatory cytokines, the outcome is less good: acute organ dysfunction can result in early death; and if the lymphopaenia phase is associated with immune suppression (see below), then opportunistic infections contribute to the worsening mortality rates.

Two underlying processes have been more recently highlighted in severe sepsis:

i. there is apoptosis of lymphocytes in the spleen and gut (Hotchkiss et al. 1999). It is hypothesised that this leads to impairment of immune responses in sepsis, following the acute phase (van der Poll.T \& Opal 2008).

ii. organ failure is not always from observable necrosis and/or fibrosis (ie structural) but is functional. There is reduction in cellular mitochondrial activity, and this 'hibernation' may be a protective response (Singer et al. 2004) (Levy et al. 2005).

There are significant controversies, including:

1. the significance of bacteraemia: does this trigger severe sepsis, or is it a transient leakage phenomenon, and contribute little, per se, to outcome?

2. the continuum of the sepsis syndromes: is this a true final common path, independent of the actual initiating infection? Or do different infection-host interactions produce severe sepsis and septic shock through different mechanisms? (Munford 2005).

3. the concept that a major determining factor in patient outcome, for any given aetiology and set of co-morbidities, is not the particular therapy in ICU but the individual's genetic make up (Annane, Bellisant, \& Cavaillon 2005) (Villar et al. 2004)?

4. The contribution of virulence factors in outcomes of sepsis (van der Poll.T \& Opal 2008)

5. it is not always evident grossly and histologically why patients with sepsis have died. A new paradigm is needed (Hotchkiss, Swanson, Freeman, \& et al 1999).

\section{Autopsy protocols}

In the UK, $>95 \%$ of adult autopsies are performed for a coroner, or (in Scotland) a procurator fiscal, under medico-legal conditions. Since the basic remit of the medico-legal autopsy is to exclude unnatural or violent death, and, if possible, to avoid having an inquest (National Confidential Enquiry into Patient Outcome and Death 2006), the level of detail of examination of cases that may have a sepsis syndrome is varied. Often the autopsy does not address the questions raised by the clinical course of the patient with sepsis. In this brief review, there is no attempt to address the requirements of what coroners might want from pathologists in '?sepsis' cases.

\section{Microbiology sampling}

One of the problems in the septic autopsy is the lack of agreed methods of sampling blood, tissues and other fluids so that

- Contamination from other organs is minimised

- The consequences of the post-mortem spread of gut flora bacteria into the blood and tissues is minimised (Morris, Harrison, \& Partridge 2006) 
Also there are no agreed strategies of what to sample for each clinico-pathologicalmicrobiological scenario. In all cases, doing the sampling as soon after death as logistically feasible reduces the problems in the interpretation of bacterial culture results. See Table 4 for interim recommended practice.

\begin{tabular}{|l|l|}
\hline Tissue & Sampling method \\
\hline Cerebrospinal fluid & $\begin{array}{l}\text { With syringe and needle through alcohol-cleaned skin, } \\
\text { through either or both of: } \\
\text { Cisternal puncture (posterior neck below the occipital } \\
\text { protruberance; aim anteriorly for the eyes) } \\
\text { Lumbar puncture (between L4-5) }\end{array}$ \\
\hline Urine & $\begin{array}{l}\text { Syringe and needle through cleaned suprapubic skin } \\
\text { Blood }\end{array}$ \\
$\begin{array}{l}\text { Cardiac puncture blood, through the left } 4^{\text {th }} \text { intercostals space, } \\
\text { or peripheral venous blood } \\
\text { Subclavian vein (above clavicle), or } \\
\text { once the body is opened and before any organs } \\
\text { opened or removed (particularly the intestines), tie } \\
\text { off an iliac vein proximally, insert syringe needle } \\
\text { pointing distally and withdraw 10 ml blood. }\end{array}$ \\
$\begin{array}{l}\text { Inoculate } 5 \text { ml into each of aerobe and anaerobe blood culture } \\
\text { bottles. }\end{array}$ \\
\hline Cardiac vegetations & $\begin{array}{l}\text { Divide between a sterile bottle for culture and histopathology. } \\
\text { Attempts to sterilise the outer surface are probably futile. A } \\
\text { compromise is to cut the lung with a clean organ-slicing blade } \\
\text { on a clean surface and sample the relevant areas with a sterile } \\
\text { scalpel blade. }\end{array}$ \\
\hline
\end{tabular}

Table 4. Sampling autopsy tissues for microbiological culture

\subsection{Interpretation of bacteriological cultures}

In all cases, the microbiology department must be advised what range of organisms is being sought; culture set-ups and molecular diagnostic techniques vary accordingly. Interpretation of positive results is often difficult, and consultation with an experienced microbiologist is critical. In cultures, confidence that the identified organism is significant is appropriate if there is Mycobacterium tuberculosis, Streptococcus group A (pyogenes), Streptococcus pneumoniae, or Neisseria meningitides since these are most unlikely to be present incidentally or from contamination.

The introduction of the new molecular sepsis assay technologies for the rapid, sensitive and specific identification of bacterial species in blood and other samples may change much of this (Tissari et al. 2010). They have yet to be introduced into autopsy-related practice, and it will be important to determine whether they make simpler or more complicated the interpretation of post-mortem blood cultures.

\section{Non-microbiological means of identifying severe sepsis}

In many cases at autopsy, the need to confirm or exclude sepsis happens without positive microbiology, either because all attempts (including pre-mortem) were negative (perhaps 
due to anti-microbial chemotherapy), or because samples were not taken at all. Where histological evidence of pyogenic infection with definite bacteria or fungi is present, this can indicate the organ-site of the sepsis.

If no infection is identified, there is an immunocytochemical technique that may assist. In SIRS, endothelial cells are upregulated, and express cell more adhesion molecules such as ICAM-1 (intercellular adhesion molecule-1; CD54) and E-selectin (CD62E). It is possible to immunostain for these (Fig 1) and at least one author holds that positive ICAM-1 staining of alveolar capillary endothelial cells indicates septic shock with high sensitivity and specificity (Tsokos 2003).

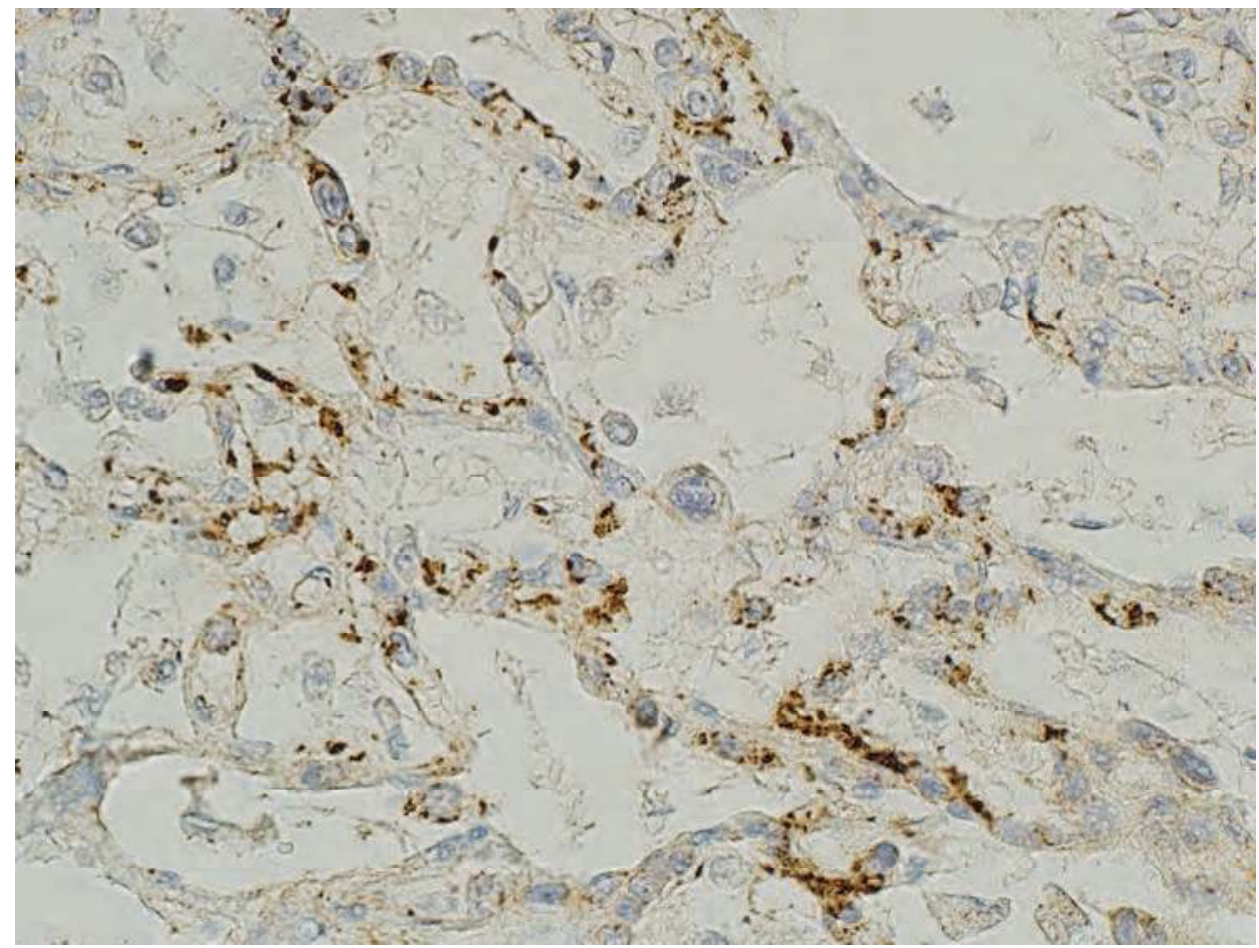

Fig. 1. Lung in septic shock, stained for CD54, showing endothelial cell (EC) upregulation (normal lung ECs do not stain).

There are suggestive reports on the estimation of post-mortem serum endotoxin level as an indicator of sepsis (Zhu et al. 2005).

\section{Simulators of septic shock}

Patients with clinical manifestations similar to those of septic shock come to ICU and die despite empirical therapy. The differential diagnosis includes

- Disseminated cancer, including carcinoma and lymphoma. For example, pulmonary micro-emboli from an occult carcinoma can obstruct pulmonary arterioles and cause cardio-respiratory failure (Hirata et al. 1988). 
- Haemophagocytic syndrome

- HHV8-associated multicentric Castleman disease syndrome in HIV-infected persons (Stebbing et al. 2011)

- Thrombotic microangiopathy syndromes

- Other conditions that mimic SIRS, but not considered in more detail (Munford 2005)

- Multi-organ atherosclerosis, NO expression being a common factor

- Burns

- Adrenal insufficiency

- Thyroid storm

- Major trauma

- Pancreatitis

- Cardio-pulmonary bypass

- Drug hypersensitivity reaction and acute anaphylaxis

- Malignant hyperthermia and heat stroke

\section{Specific organs at autopsy}

The organ pathology of sepsis comprises gross and histopathological lesions. The histopathological lesions can often identify a specific infection, or at least point to a limited range of possible infectious agents (Table 5). 'Pathology' is, essentially, the study of host reaction to injury. Thus in the diagnosis of sepsis there are the two complementary pathways for evaluating infectious disease:

1. the gross pathology

2. the microscopic pathology (histopathology and cytopathology), which is subdivided into:

- identification and quantification of infectious agents

- categorising the host inflammatory reaction, or absence of reaction

Considering acute host inflammatory reactions, they can be considered as shown in Table 5.

\subsection{Heart}

The syndrome of sepsis-related myocardial dysfunction includes reduced left and right ejection fractions and elevated heart rate (Table 6) (Munford 2005). There is evidence of apoptotic damage to cardiac myofibres in the rodent model of sepsis (Ha et al. 2006). But the clinical experience of patients surviving sepsis is that there is no evidence of persistent cardiac defects attributable to such a process. Presumably, the dysfunction is cytokine driven and reversible (Levy, Piel, ACton, \& et al 2005). The heart in autopsied non-survivors shows prominent interstitial mononuclear cells - this is not myocarditis but mainly enlargement of capillary endothelial cells, as part of the generalised endothelial upregulation phenomenon.

Given the generally old age of patients admitted to ICU with sepsis, many will have coronary artery disease, with or without previous myocardial infarction, at autopsy. The extent to which this contributes (if at all) to death needs to be carefully considered in the context of the whole case. The Davies scale of certainty for ischaemic heart disease death (although designed for sudden cardiac death in the community) is a bench-mark from which to work (Royal College of Pathologists 2005). Nothing irritates ICU clinicians more than to be told that the cause of death was 'ischaemic heart disease' in a complex case of 


\begin{tabular}{|c|c|c|}
\hline Pattern of inflammation & $\begin{array}{l}\text { Quantity of } \\
\text { infectious } \\
\text { agent }\end{array}$ & Example \\
\hline Haemorrhage only & - to +++ & Anthrax, streptococcal skin rash \\
\hline Minimal inflammation & +++ & $\begin{array}{l}\text { Neutropaenic sepsis } \\
\text { (many bacteria types, including } \\
\text { anergic tuberculosis) }\end{array}$ \\
\hline Usual acute inflammation & - to +++ & $\begin{array}{l}\text { Pneumococcus, other } \\
\text { streptococci, gram-ve bacilli, } \\
\text { anergic tuberculosis }\end{array}$ \\
\hline $\begin{array}{l}\text { No inflammation; vasculopathy } \\
\text { and necrosis }\end{array}$ & +++ & $\begin{array}{l}\text { Pseudomonas vasculitis, } \\
\text { toxoplasmosis }\end{array}$ \\
\hline $\begin{array}{l}\text { Necrosis and inclusion bodies } \\
\text { (intranuclear and/or } \\
\text { intracytoplasmic) }\end{array}$ & + to +++ & Virus infections: herpes, Ebola \\
\hline $\begin{array}{l}\text { Mixed granulomatous and acute } \\
\text { inflamation }\end{array}$ & - to +++ & Melioidosis, tularaemia, typhoid \\
\hline Chronic inflammation & - to + & Chagas' disease \\
\hline Necrosis, no inflammation & +++ & $\begin{array}{l}\text { Strep.pyogenes (necrotising } \\
\text { fasciitis), Clostridium perfringens, } \\
\text { leptospirosis }\end{array}$ \\
\hline Vasculitis and thrombosis & + to +++ & $\begin{array}{l}\text { Pseudomonas, meningococcus } \\
\text { (Fig 2,3) }\end{array}$ \\
\hline Botryomycosis & +++ & Staphylococcus aureus \\
\hline $\begin{array}{l}\text { No inflammation, parasites in } \\
\text { vessels }\end{array}$ & + to +++ & Malaria \\
\hline
\end{tabular}

Table 5. Some consistent patterns of inflammation associated with particular infections 
multi-organ failure and sepsis. If the patient was part of a therapeutic protocol trial, it is even more unfortunate, as the aspects of apparent therapy failure will be mis-apportioned.

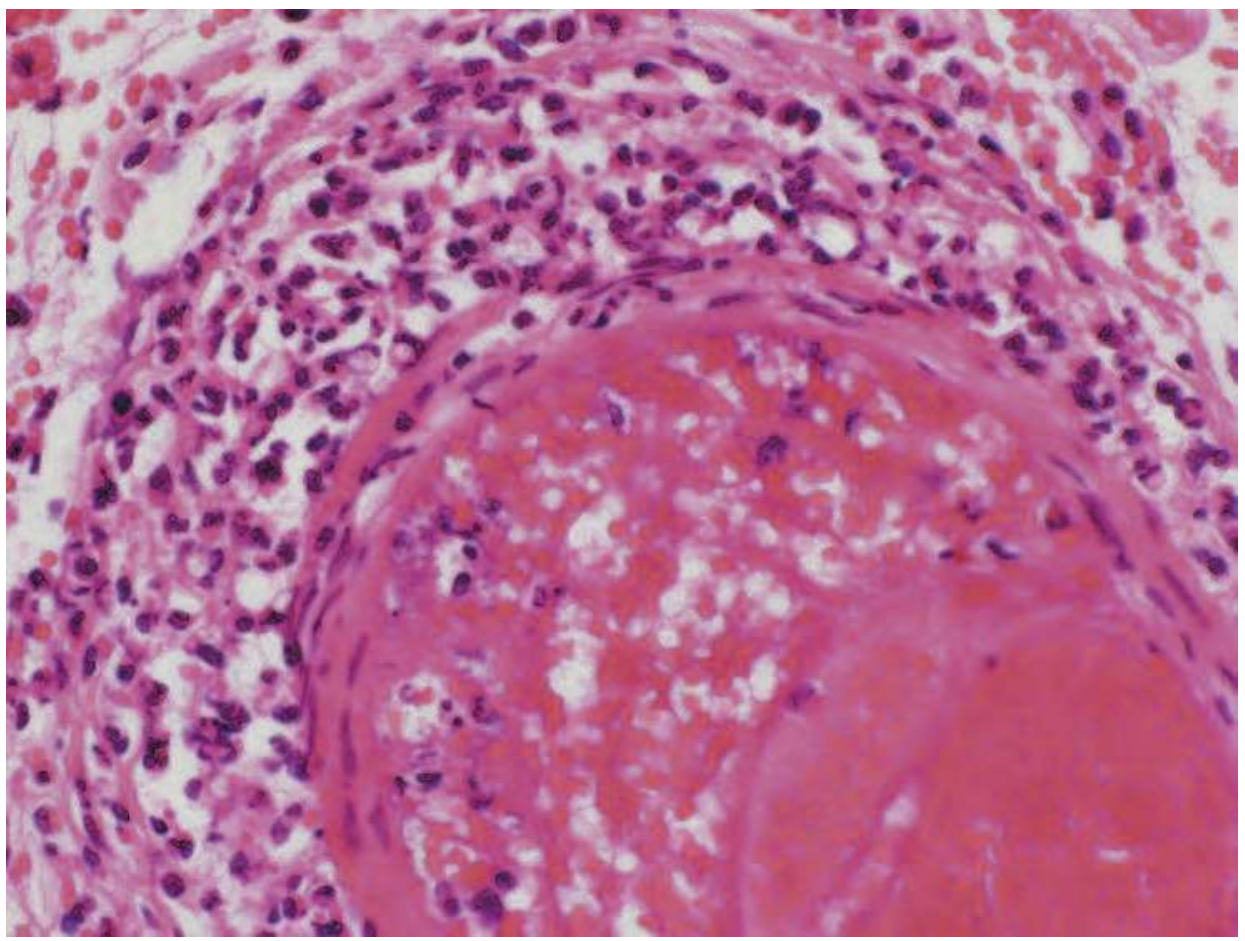

Fig. 2. Skin in a fatal case of meningococcal sepsis. The artery is vasculitic and thrombosed $(\mathrm{H} \& \mathrm{E})$ 


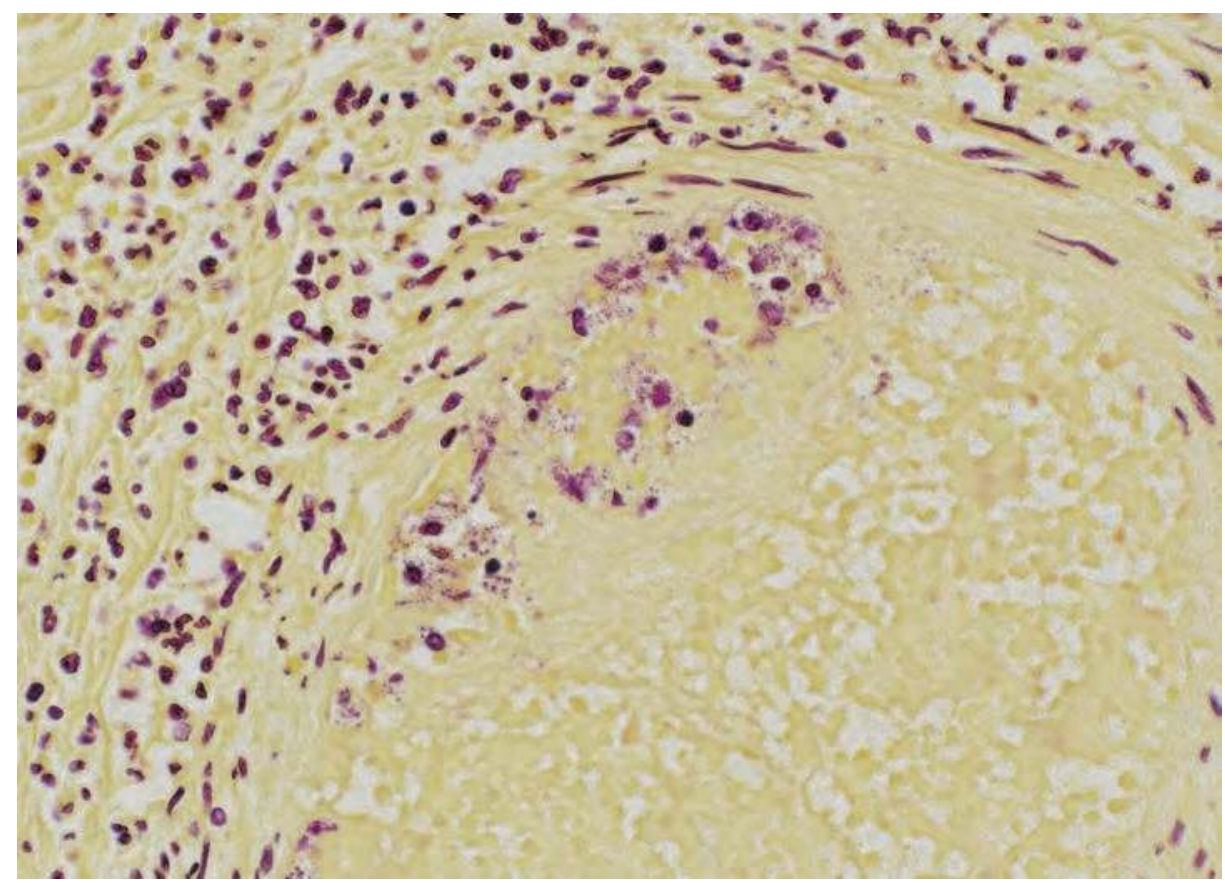

Fig. 3. Same vessel as in Fig 2, stained with Brown-Hopps gram stain, to demonstrate gramve cocci in the lumen and endothelium

\begin{tabular}{|l|l|l|c|c|c|}
\hline & $\begin{array}{l}\text { Ischaemic } \\
\text { Necrosis } \\
\text { (atonic } \\
\text { fibres) }\end{array}$ & $\begin{array}{l}\text { Contraction } \\
\text { band } \\
\text { necrosis } \\
\text { (hyper- } \\
\text { contracted } \\
\text { fibres) }\end{array}$ & $\begin{array}{l}\text { Interstitial } \\
\text { inflammation }\end{array}$ & Myocarditis & $\begin{array}{l}\text { Interstitial } \\
\text { haemorrhage }\end{array}$ \\
\hline $\begin{array}{l}\text { Myocardial } \\
\text { Infarction }\end{array}$ & + & - & - & - & + \\
\hline $\begin{array}{l}\text { Re-perfusion } \\
\text { Injury }\end{array}$ & + & + & - & - & + \\
\hline $\begin{array}{l}\text { Inotropes \& } \\
\text { cocaine }\end{array}$ & + & + & - & - & + \\
\hline Sepsis & $+/-$ & - & + & $+/-$ & + \\
\hline $\begin{array}{l}\text { Infective } \\
\text { endocarditis }\end{array}$ & $+/-$ & - & + & + & + \\
\hline $\begin{array}{l}\text { Cardio- } \\
\text { pulmonary } \\
\text { resuscitation }\end{array}$ & + & + & - & - & + \\
\hline
\end{tabular}

Table 6. Cardiac pathologies encountered in ICU patients and sepsis syndromes (Baroldi 2006) ; (Nishida et al. 2006) 


\subsubsection{Heart examination}

Given the subtle nature of cardiac lesions in sepsis and its treatment, there is an argument for proper histopathological examination of a complete horizontal slice, with a minimum of 5 blocks taken: 2 from the right ventricle in one block, and one full thickness section from each left ventricular quadrant (Royal College of Pathologists 2005).

\subsection{Brain}

At the gross and standard microscopic level, the brain is not directly affected by sepsis and septic shock. This matches the lack of imaging-detected damage despite the common clinical cognitive and performance deficiencies (Munford 2005), and is presumably a transient cytokine-based phenomenon. However, certain cerebral pathologies are associated with sepsis syndromes for more tangible reasons, including:

- Cerebral infarction from thrombo-embolisation

- Hypoxic-ischaemic encephalopathy (HIE) following temporary cessation of blood and/or oxygen supply during a crisis

- Metastatic cerebral abscess and/or meningitis from a remote focus of sepsis

- Microinfarction from thrombotic microangiopathy affecting all areas of the brain

In the case of HIE, post-mortem pathology does not form part of the case definition, which is solely clinical, neurophysiological and radiological. The most sensitive zones of the brain for such damage are the cerebellar nuclei and the hippocampus, followed by the cerebral cortex in the watershed areas at the junctions of the cerebral artery supply zones. It is useful to sample these to confirm HIE, and to be aware of the problem with artefacts (Whitwell 2005)

\subsection{Lung}

Lung dysfunction at the commencement of severe sepsis is present in about $20 \%$ of such patients (Munford 2005).The clinical diagnosis of acute lung injury is made when there arterial hypoxaemia $(\mathrm{PaO} 2 / \mathrm{FiO} 2<300 \mathrm{mmHg})$ and bilateral chest pulmonary infiltrates on chest $X$ ray, in the absence of pneumonia or heart failure. It becomes acute respiratory distress syndrome (ARDS) when hypoxaemia is more severe $(\mathrm{PaO} 2 / \mathrm{FiO} 2<200 \mathrm{mmHg})$. Ventilation/perfusion mismatch (effectively right-to-left shunting) of blood flow occurs, exacerbating the hypoxaemia.

Pathologically, the process is diffuse alveolar damage (DAD). This is not specific to the sepsis syndromes as it also occurs in inhalational injury (smoke, toxic gases, oxygen in high concentration), aspiration of gastric contents, and X-irradiation damage; these represent direct damage to the lung tissue. DAD also follows from remote injury as part of SIRS, the pathogenesis being mediators in the blood stream; the causes include cytotoxic drug therapy, pancreatitis, cardio-pulmonary bypass, blood transfusion reaction, fat embolism, paraquat poisoning, and systemic shock from any cause (Corrin \& Nicholson 2011). Reduction of surfactant through epithelial cell damage is a key event, which leads to further alveolar and alveolar duct damage.

DAD goes through stages termed the exudative, regenerative, and repair phases.

The exudative phase lasts up to a week, and grossly the lungs are dark red and heavy. The early stage histologically comprises:

- Alveolar wall congestion and expansion

- Variable neutrophils in the interstitium (usually not)

- Oedema and red cells in the alveolae 
- $\quad$ Type 1 epithelial cell and alveolar capillary endothelial cell damage (but this is difficult to identify on light microscopy)

The later exudative phase is the classic and, histologically, readily identifiable stage often termed 'shock lung' (Fig 4):

- Alveolar collapse, haemorrhage and oedema

- Hyaline membrane formation on the epithelial surface of respiratory bronchioles and alveolar ducts: this comprises fibrin and necrotic epithelial cells

- Variable neutrophil accumulation in alveolar capillaries

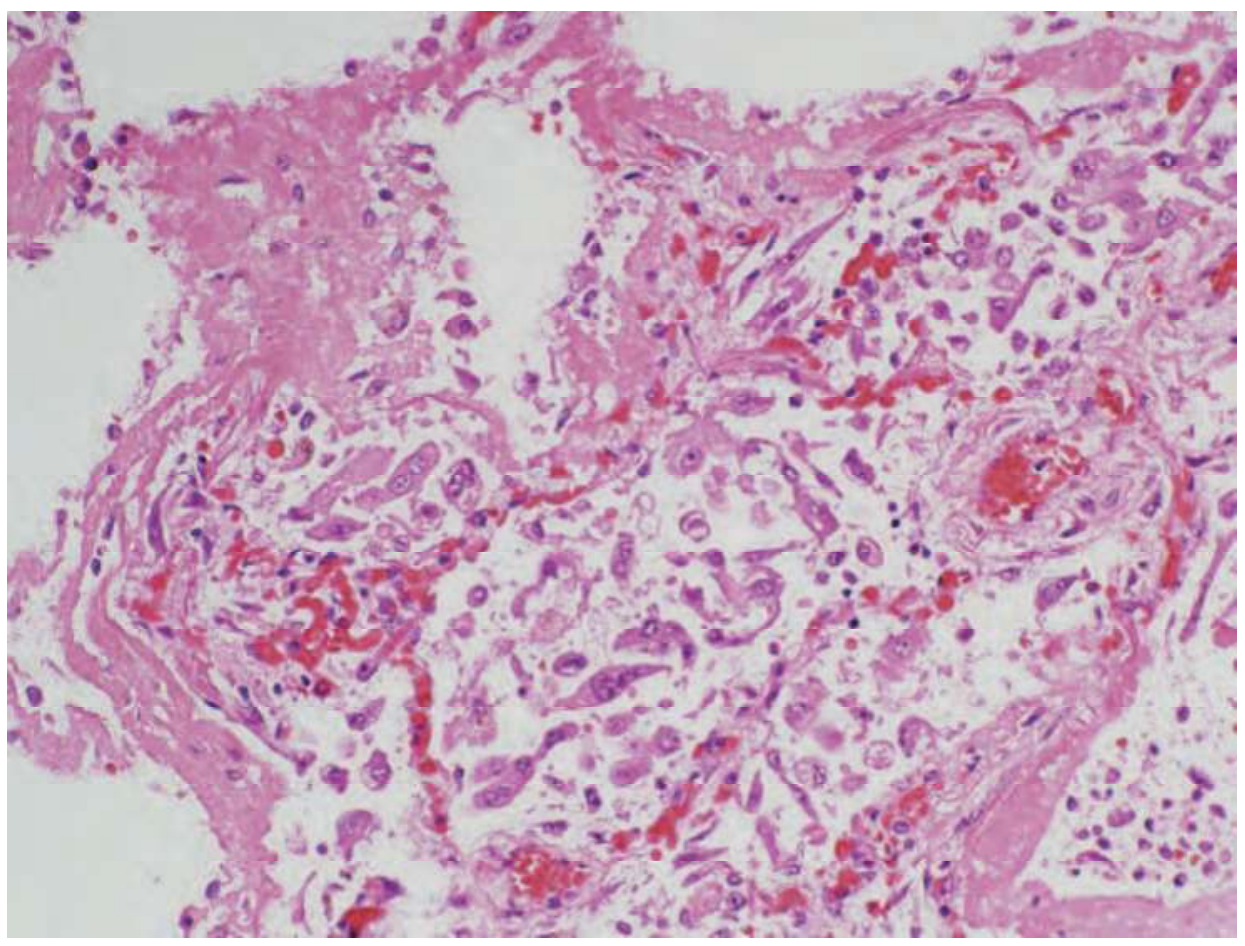

Fig. 4. Hyaline membrane disease in the lung alveoli in septic shock; the pink membranes are partly fibrin exudates and partly necrotic epithelium (H\&E)

The regenerative phase permits healing and recovery of the lung to normal structure or progresses to fibrosis via the repair phase. Type 2 epithelial cells proliferate to replace the denuded epithelium; they may be large and elongated, resembling macrophages in the airways. The epithelium may regrow beneath the hyaline membrane, which is sloughed off; or over the membrane, in which case it becomes incorporated into the alveolar wall and is a mechanism for interstitial fibrosis. In the capillaries, the endothelial repair may be accompanied by local thrombosis, organisation and local vascular remodelling.

The repair phase occurs in those whose DAD has not resolved through regeneration. As well as the progressive interstitial thickening from incorporation of hyaline membranes and the ingress of fibroblasts into this tissue, the alveolar exudates organise. There are granulation tissue buds in the alveoli, as seen in organising pneumonias. This 
fibrosis can happen within a few weeks, if the patient is maintained and alive (Vincent \& Singer 2010).

In practice, if patients survive long periods in ICU with episodes of severe sepsis and infective pneumonia and have been mechanically ventilated for long periods, the resulting lung tissue at autopsy can show a varied pattern with some areas of nearly normal tissue, organising pneumonia and interstitial fibrosis separately and combined: it can be difficult if not impossible to ascribe specific aetio-pathogeneses to this end-stage lung fibrosis (Fig 5).

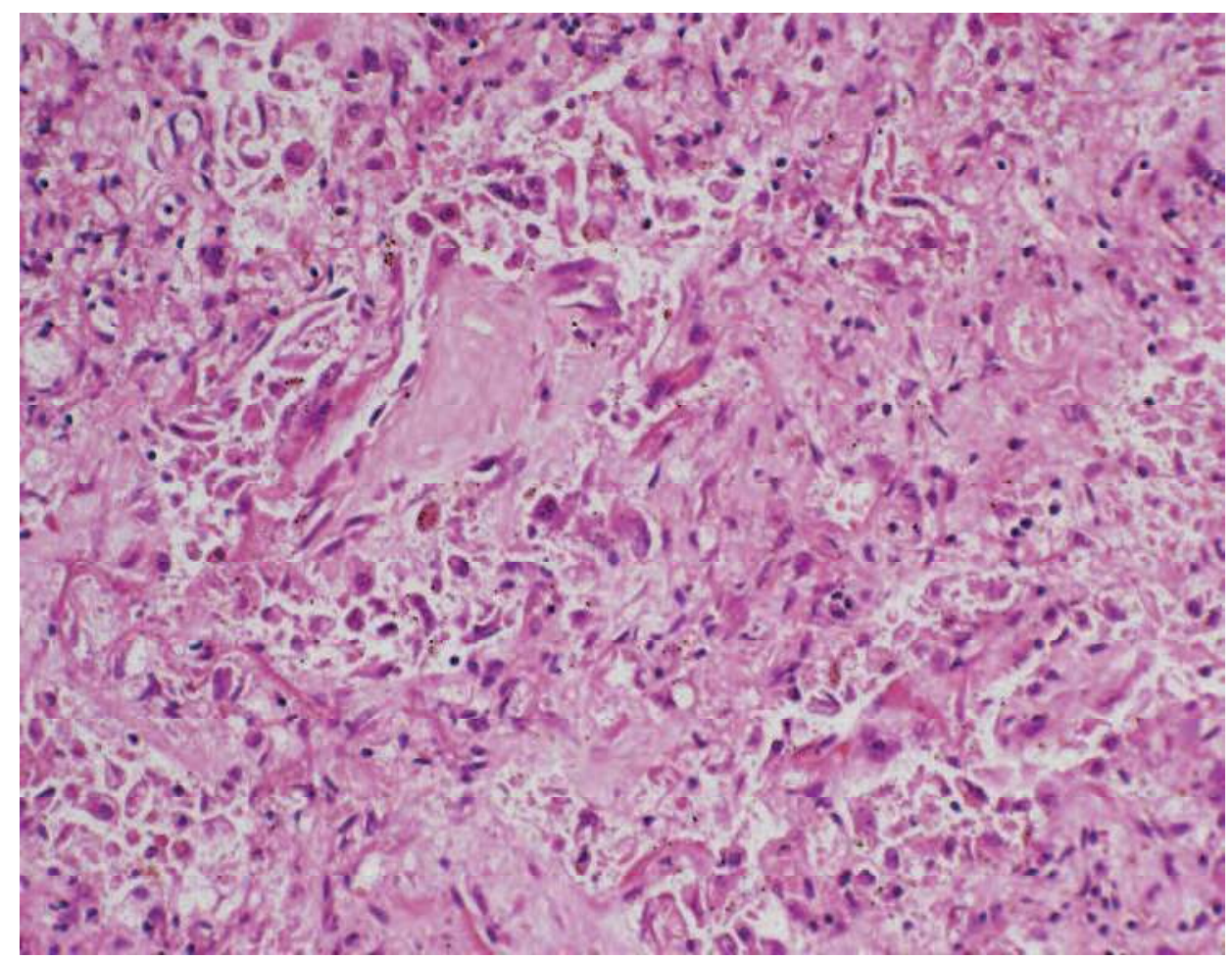

Fig. 5. Acute lung injury that has gone on to organisation with fibrosis, obliterating the alveoli (H\&E).

It is unresolved why some patients with DAD in whom the infecting agent is identified and treated promptly still go on to the repair phase and died of pulmonary fibrosis (Wheeler \& Bernard 2007). This is particularly seen in patients presenting as advanced HIV disease with Pneumocystis infection, and despite co-trimoxazole plus steroid cover become progressively hypoxic; at autopsy the lungs show combined intra-alveolar and interstitial fibrosis.

\subsubsection{Ventilator-associated pneumonia (VAP)}

VAP is an important entity in ICU, as the development of lung infection during respiratory support demands a change in therapy. There have been several studies of the diagnostic criteria for VAP in vivo (microbiology and cytopathology) and at autopsy (histopathology), and the results are unsettling (Corley et al. 1997) (4177): 
- There are no agreed criteria for diagnosing pneumonia in man by histology

- Pathologists do not agree amongst themselves whether there is pneumonia or not

- Quantitative pre-mortem bacteriology does not correlate with clinical symptoms or autopsy histopathology

- Bronchiolar lavage fluid with few neutrophils does correlate with absence of histological pneumonia

Evidently pathology is not yet serving clinical science optimally in this area.

\subsubsection{Neutropaenic sepsis}

This is a common terminal condition in patients with treated cancer. Bacteria proliferate in many organs and blood vessels, and in the lung they are visible in the alveoli with fibrin and mononuclear cells (Fig 6).

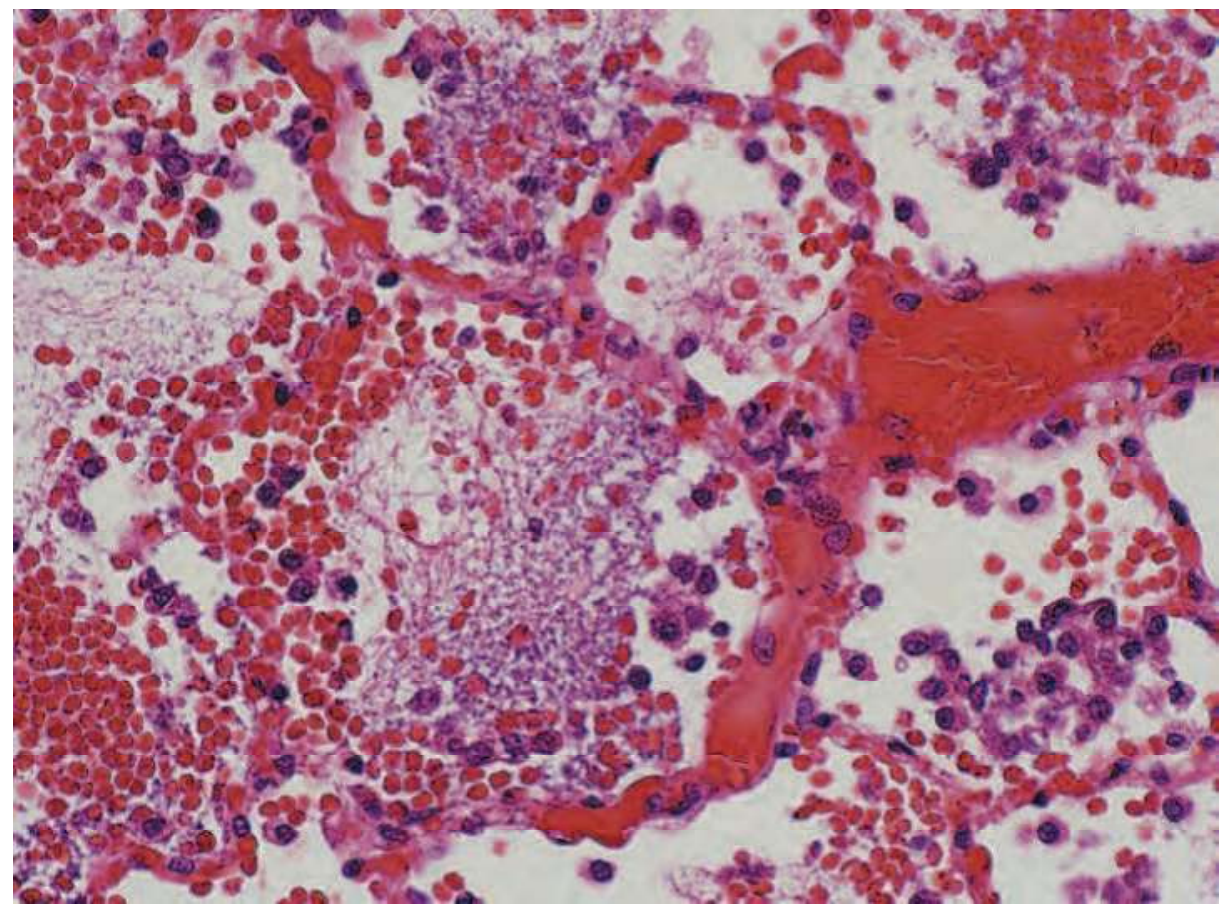

Fig. 6. Lung alveoli in neutropaenic sepsis. There are abundant bacteria in the lumens, some haemorrhage, but only scanty inflammation (H\&E)

\subsection{Liver}

The liver in septic shock has no specific features (Table 6). Clinically, there is cholestatic jaundice. If the source of the sepsis is the biliary tract (cholangitis) there may be abscesses centred on portal tracts. Otherwise, the liver is usually heavier than normal, bile stained, and soft. Histologically, autolysis with cell plate separation is often more advanced than expected from the time since death (perhaps due to high levels of TNFa). There is often fatty change, but usually little parenchymal inflammation, although the sinusoid Kupffer cells 
and endothelial cells are prominent, and there may haemophagocytosis. Centriacinar necrosis is often prominent.

Several patterns of bile duct histopathology are described, although none are specific to sepsis (Scheuer \& Lefkowitch 2006):

- Intracanalicular cholestasis in the perivenular areas

- Ductular cholestasis, proliferating ductules, and surrounding portal neutrophilic inflammation, in addition to canalicular cholestasis

- Non-bacterial cholangitis, with proliferating bile ductules; this is seen in the toxic shock syndrome (Fig 7).

\begin{tabular}{|c|c|c|c|c|c|c|}
\hline & \multirow[b]{2}{*}{$\begin{array}{l}\text { Liver } \\
\text { abscess }\end{array}$} & \multirow[b]{2}{*}{$\begin{array}{l}\text { Bacterial } \\
\text { cholangitis }\end{array}$} & \multirow[b]{2}{*}{$\begin{array}{l}\text { Bile duct } \\
\text { obstruction }\end{array}$} & \multicolumn{3}{|c|}{ Severe sepsis patterns } \\
\hline & & & & $\begin{array}{l}\text { Canalicular } \\
\text { cholestasis }\end{array}$ & $\begin{array}{c}\text { Ductular } \\
\text { cholestasis \& } \\
\text { inflammation }\end{array}$ & $\begin{array}{c}\text { Non- } \\
\text { bacterial } \\
\text { cholestasis }\end{array}$ \\
\hline $\begin{array}{l}\text { Perivenular } \\
\text { cholestasis }\end{array}$ & $+/-$ & - & + & + & + & - \\
\hline $\begin{array}{l}\text { Canal of Hering \& } \\
\text { ductular cholestasis }\end{array}$ & - & - & - & - & + & - \\
\hline $\begin{array}{l}\text { Ductular } \\
\text { proliferation }\end{array}$ & - & + & + & - & + & + \\
\hline $\begin{array}{l}\text { Ductular acute } \\
\text { inflammation }\end{array}$ & $+/-$ & + & $+/-$ & - & + & + \\
\hline $\begin{array}{l}\text { Parenchymal } \\
\text { necrosis }\end{array}$ & + & + & $+/-$ & - & - & - \\
\hline
\end{tabular}

Table 6. Liver histopathology in sepsis

\subsection{Kidney}

Acute renal failure occurs in one fifth of patients becoming septic, rising to $50 \%$ in septic shock (Munford 2005) (Racusen \& Kashgarian 2007). It is the commonest organ dysfunction, manifesting as oliguria and azotaemia. The pathogenesis of the damage in sepsis includes systemic hypotension, renal vasoconstriction, toxic drugs (eg antibiotic aminoglycosides), and inflammatory cytokines.

The pathological lesion is acute tubular injury (ATI), which replaces the older term 'acute tubular necrosis' (Racusen \& Kashgarian 2007). Grossly the kidneys are enlarged (oedematous cortex) and typically pale, with blurred cortico-medullary junctions. Focal pyaemic lesions, ascending acute pyelonephritis lines, and (where arterial thrombi are formed) regional cortical infarctive necrosis may also be seen in some cases.

ATI can only be reliably evaluated microscopically. The glomeruli may be collapsed but otherwise show no damage. The tubular damage is conceptually divided into 'ischaemic' and 'toxic' (Racusen \& Kashgarian 2007), with more extensive proximal tubule lesions, and more evident cell death, in the latter. In septic shock, with the aetio-pathogenesis often multi-factorial, the distinction becomes blurred. Moreover, autopsy kidneys are notoriously autolysed unless analysed rapidly after death. The main features of ATI are (Fig 8):

- Interstitial oedema with separation of tubules

- Tubular cell swelling

- Loss of nuclei of tubular cells or apoptosis

- Shedding of tubule cells into the lumen 


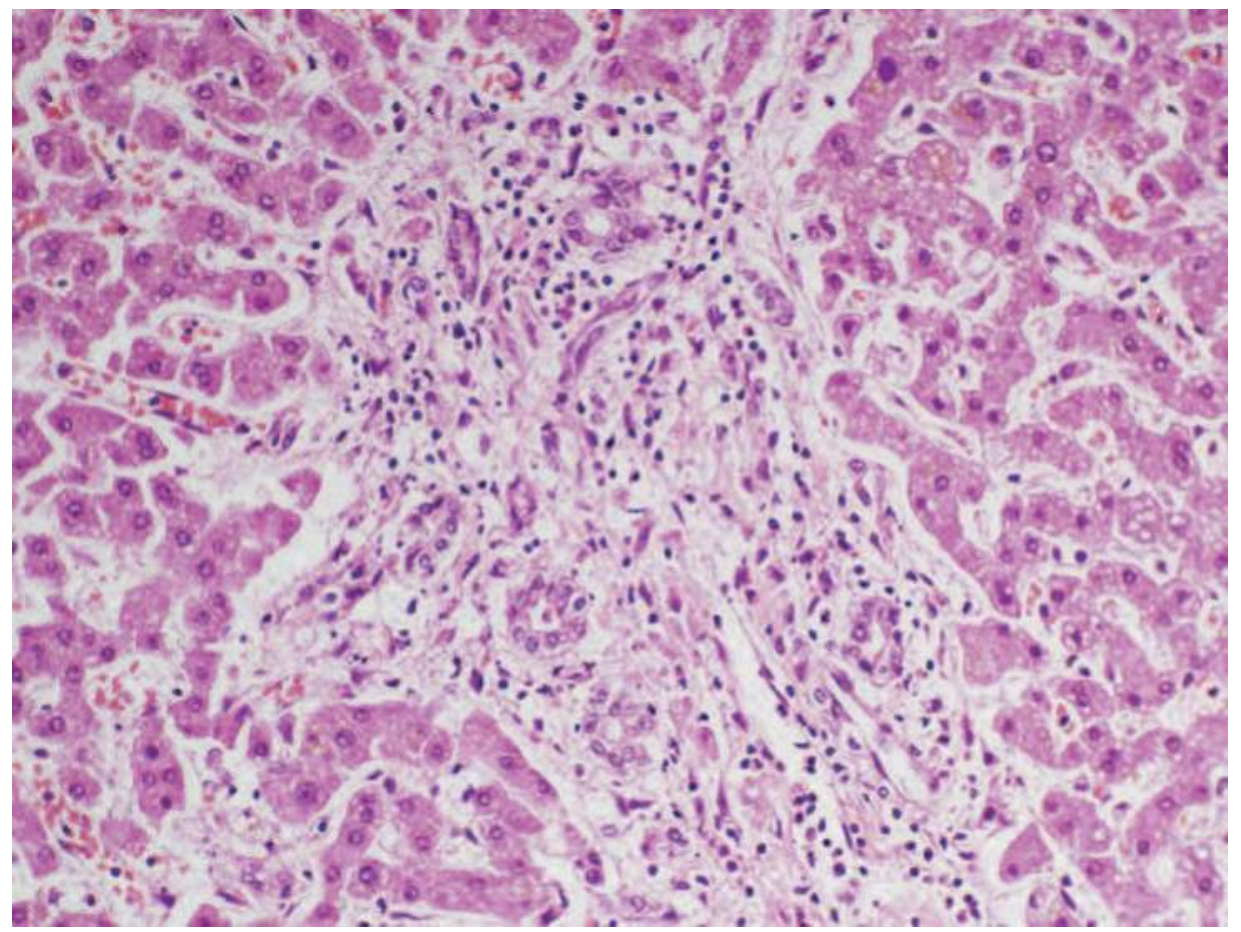

Fig. 7. The portal ductular prolferative reaction in systemic sepsis, with inflammation (H\&E)

- Attenuation of the tubular epithelium thickness

- Regeneration of tubular cells: hyperchromatic enlarged nuclei, often adjacent; mitoses

- Insignificant interstitial inflammation

- Accumulation of nucleated cells in the vasa recta in the outer medulla; lymphocytes, myeloid precursors, and nucleated red cell precursors

All too often, the time delay to autopsy precludes confirmation of these features through autolysis. Microvesicular vacuolation of proximal tubules is not ATI, but the result of medical drugs and dextrose-containing plasma expanders.

\subsection{Adrenal glands}

The adrenals may show the following features

- $\quad$ Lipid depletion and hyperplasia

- Atrophy (if prolonged steroid therapy has been given)

- Parenchymal haemorrhages, small or large

- Thromboses in small arterioles

\section{Haemophagocytic syndromes}

There is a group of conditions termed 'haemophagocytic syndromes' (HPS) where the driving process is excessive phagocytosis of formed blood cells by macrophages in the marrow, spleen and lymph nodes (Fig 9). The clinical outcomes include: 


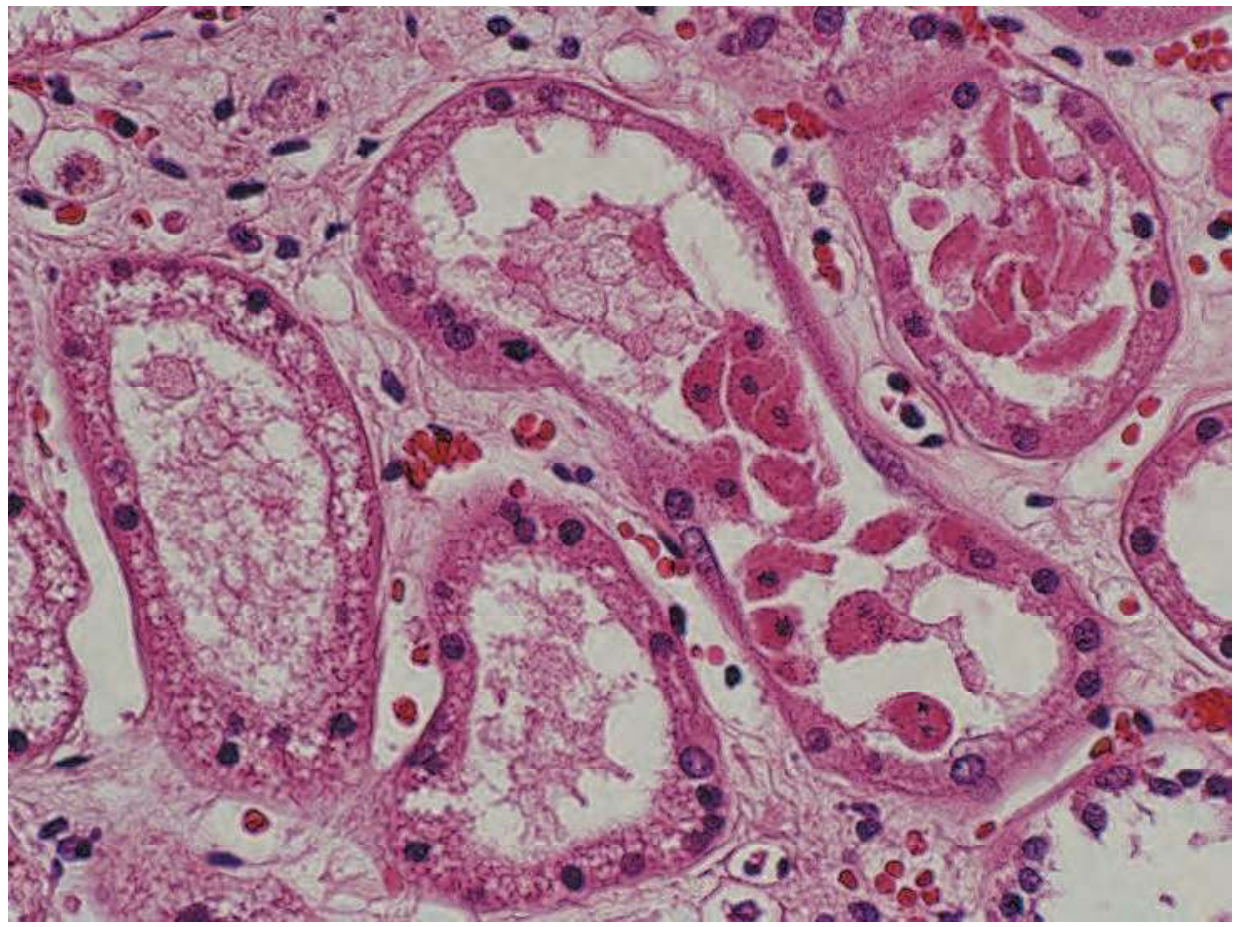

Fig. 8. Kidney in acute tubular necrosis (acute tubular injury). The necrosing epithelium is sloughing into the lumen (H\&E)

- High fever

- Pancytopaenia

- Liver dysfunction

- Clotting abnormalities including raised fibrin degradation products and hypofibrinogenaemia

- Hepatosplenomegaly

- Hyperferritinaemia

Thus HPS overlaps clinically with septic shock by case definition (Fisman 2000). The mortality is high, up to 70\% (Takahashi et al. 2001) (Ningsanond 2000) From personal experience, many cases that turn out to be HPS have been patients presenting acutely with SIRS, infection screens are negative, and the patients die within a week, of multi-organ failure, despite antibiotics, steroids and standard ICU support procedures.

The pathogenesis of HPS is considered to be an aberrant immunological over-reaction, the hyperstimulation of macrophages by cytokines (particularly TNFa, IL-6, IL-1 and IFNY) as result of T-cell activation. In addition to a rare familial HPS, the aetiologies include infections, autoimmune disease (particularly SLE) and lymphoma (particularly T-cell lymphoma, but also B-cell). The potential causative infections are legion (Takahashi, Chubachi, Kume, \& et al 2001) (Ningsanond 2000) (Fisman 2000):

- Viral - eg EBV, HHV8, HIV (multi-centric Castleman disease), CMV, B19, rubella, viral hepatitis 
- $\quad$ Bacteria - eg pneumococcal, typhoid

- Mycobacteria - tuberculosis

- Fungi - eg histoplasmosis

- Protozoa - eg leishmaniasis

Bone marrow haemophagocytosis is found in one third of ICU non-survivors, associated positively with sepsis and blood transfusion, and negatively with cardiovascular disease (Stauss et al. 2004). Thus the distinction between a non-specific reactive process and a syndrome is currently blurred.

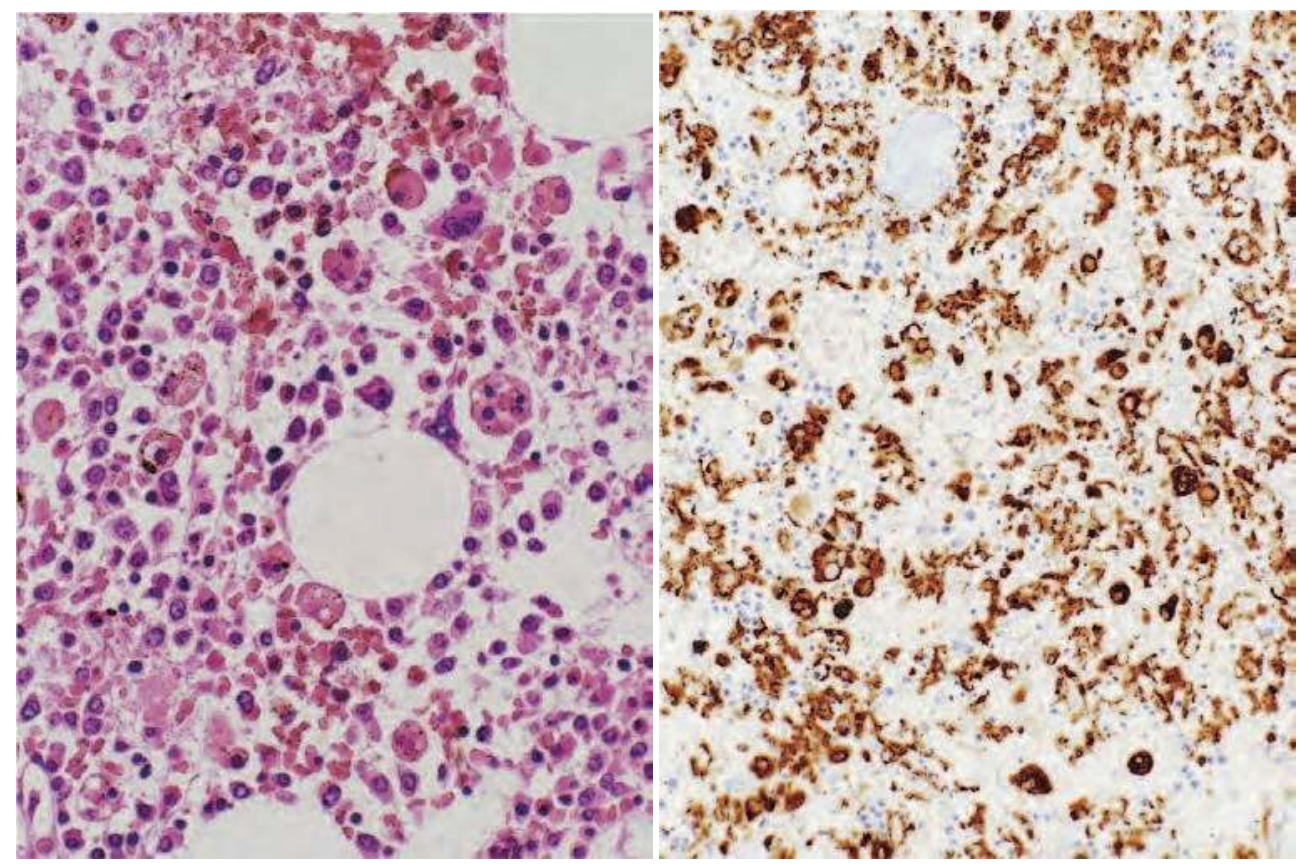

Fig. 9. Bone marrow with haemophagocytosis. Left: numerous large macrophages with engulphed red cells and nuclei (H\&E). Right: CD68 immunostaining to highlight the excess number of large macrophages.

\section{Thrombotic microangiopathy syndromes}

Thombi are frequently encountered in small vessels in sepsis and other conditions. The thrombi are composed of fibrin and platelets in varying proportions. There are two groups of conditions to consider: disseminated intravascular coagulation (DIC) and thrombotic microangiopathy (TTP variant).

\subsection{Disseminated intravascular coagulation (Toh \& Dennis 2003)}

The thrombi are predominantly composed of fibrin and it is accompanied by coagulopathy with depletion of coagulation factors in the blood. DIC (as defined by laboratory criteria) occurs in up to half of patients with severe sepsis (van der Poll.T \& 
Opal 2008). The pathogenesis is not well understood but may be endothelial injury and the expression of tissue factor on infected monocytes, and initiation of the clotting cascade (Munford 2005). With the exception of meningococcal septicaemia, autopsy studies do not show a correlation of organ dysfunction and deposition of microthrombi in DIC. When thrombi are seen, the kidney glomeruli and lung alveolar capillaries are the commonest location (Fig 10).

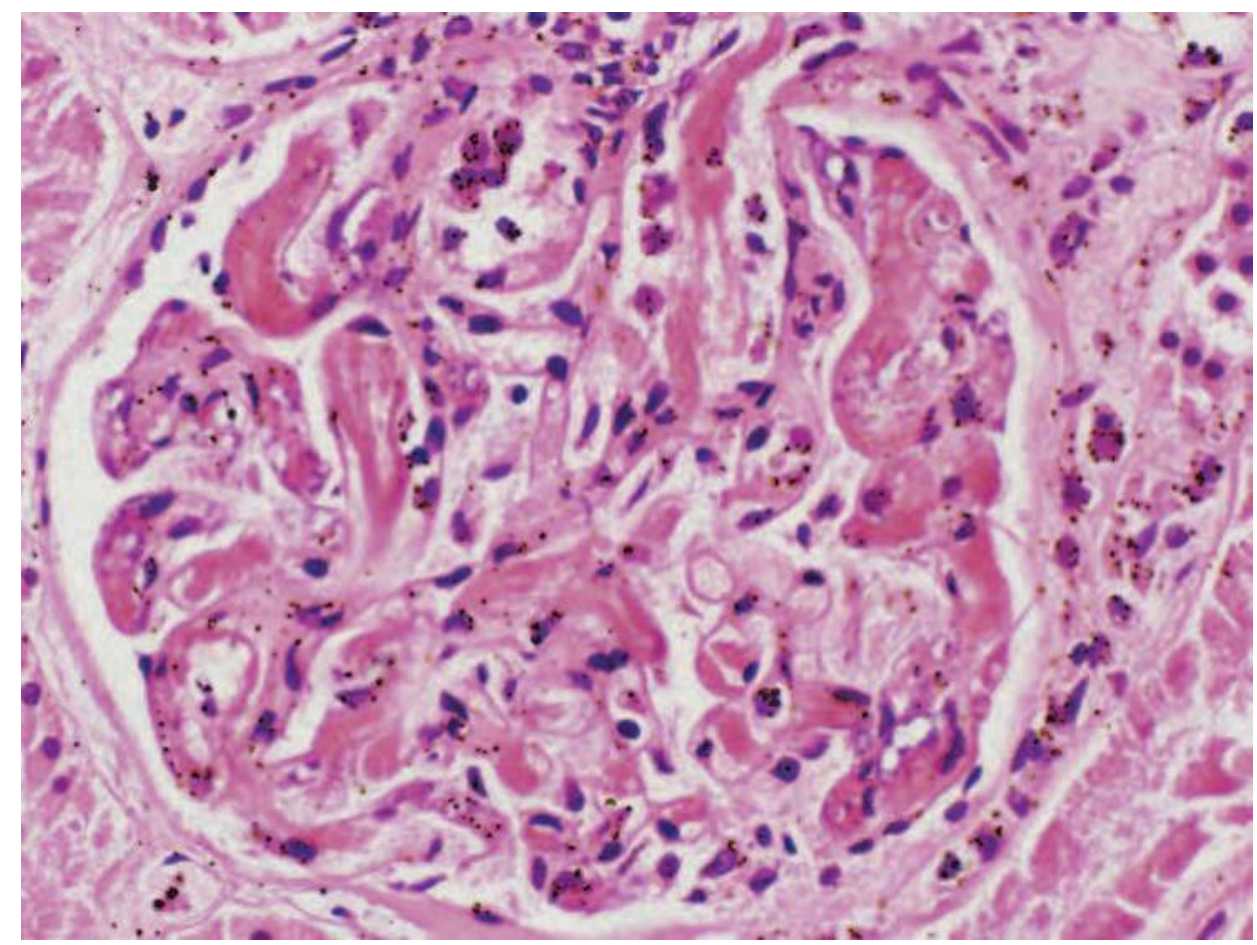

Fig. 10. DIC in pneumococcal sepsis. In this renal glomerulus, all the capillaries are blocked by thrombi (H\&E).

Neisseria meningitidis infection causes a fulminant meningococcaemia (and this is often found without a meningitis). Here DIC is the norm, and bacteria may be found within dermal vessels (Fig 3). Meningococci are different from other gram-negative bacilli as they shed membrane blebs that active complement and coagulation directly. Widespread skin and internal organ haemorrhages are seen, associated with small vessel DIC, and the adrenal shows haemorrhages (though rarely a massive destructive haematoma).

A prototype TMA is thrombotic thrombocytopaenic purpura (TTP) and the related haemolytic uraemic syndrome (Hosler, Cusumano, \& Hutchins 2003). Unlike DIC, the clotting factors are not affected, and the thrombi are predominantly platelets. Clinically TMA may simulate septic shock. Using immunocytochemistry to quantify fibrin versus platelets (anti-fibrin and anti-CD61 antibodies respectively) and thus distinguish TMA from DIC is not always helpful: the staining intensities can be similar in both conditions. 


\section{End-stage liver disease (ESDL)}

The adverse impact of cirrhosis is well-attested in many medical and surgical conditions. The Child-Pugh liver score (a measure of hepatic and extra-hepatic dysfunction based on combined biochemical markers and clinical signs) predicts non-survival in cirrhotic patients admitted to ICU. Overall, the one-year mortality of such patients is $69-74 \%$, with median survival of one month (Gildea et al. 2004) (Arabi et al. 2004).

Cardiac operations are hazardous in cirrhotic patients, with those on cardio-pulmonary bypass particularly liable to die (Hayashida et al. 2004) and - if they are Child-Pugh class C - approach a $100 \%$ mortality. Similarly, abdominal trauma patients have ICU post-operative mortality rates increasing from $15-63 \%$ as the severity liver failure increases (Christmas et al. 2005). In these patients a major cause of death is sepsis and septic shock. The abnormal blood circulation to cirrhotic liver tissue renders the Kupffer cell macrophages less able to clear bacteria from the blood.

It is the experience of pathologists examining patients who die in ICU that cirrhosis is significantly under-diagnosed pre-mortem, and that clinicians would like better methods of identifying the patients who have cirrhosis. There are several implications. First, consider liver disease carefully in ICU and sepsis deaths. The eyeball confident diagnosis of cirrhosis - or not - is not always possible. Secondly, in the formulation of cause of death in these cases, 'cirrhosis' should be included as a contributor to mortality in the death certificate.

Thirdly, liver biopsy is the only pre-autopsy definitive marker of liver fibrosis and cirrhosis; but it is invasive and has a mortality rate. Imaging, standard biochemical tests, serum markers of fibrosis, and more specialised tests of liver function only identify a proportion of cirrhotic patients (Rockey \& Bissell 2006), and these non-invasive tests have not been validated for 'normal' patients about to undergo cardiac surgery or those already in ICU for other reasons. Further research into better indicators of cirrhosis is urgently needed.

\section{Outcomes and co-morbidities}

Mortality in patients with septic shock is highly variable, from 35-70\% depending on many variables that include (Annane, Bellisant, \& Cavaillon 2005)

- $\quad$ age \& sex

- co-morbidities and other altered physiological states

- $\quad$ sickle cell disease and other hyposlenic states (Di Sabatino, Carsetti, \& Corrazza 2011)

- immunosuppression (Morris, Masur, \& Huang 2006) (Combes, Mokhtari, Couvelard, \& et al 2004)

- chronic obstructive pulmonary disease

- ischaemic heart disease

- end-stage liver disease

- pregnancy

- the combined total of failing organs, particularly lung and kidney

- whether the infection is nosocomial or polymicrobial

- whether the infection is a fungus

- $\quad$ ethnicity and inherited variables (Villar, Maca-Meyer, Perez-Mendez, \& Flores 2004) 


\subsection{Pregnancy}

The subject of susceptibility to infection during pregnancy is under-investigated epidemiologically. The depressed cell-mediated immunity during gestation does predispose to certain infections such as tuberculosis, Listeria and some viral infections. But despite the importance of bacterial infections in peri-partum sespsis, particularly Streptococcus pyogenes, it is unclear whether the pregnant state per se confers an increased susceptibility to them (Lucas 2011).

\section{The treatment of sepsis}

ICU treatment of patients in sepsis and shock has four main approaches

- Anti-microbial therapy of known or suspected infective agents

- Failing organ support - eg pulmonary, renal, hepatic, cardiac

- Indirect therapies aimed at the systemic inflammatory response and its consequences: immunomodulatory and anti-inflammatory therapies

- $\quad$ Surgical treatment - excision of septic foci and removal of necrotic tissue (eg infarcted bowel, necrotising fasciitis)

As well as inotropic and renal support, a major function of ICU is ventilatory support. In $\mathrm{DAD}$, the alveoli shut down on expiration and require a higher pressure to re-open. Mechanical ventilation thus exerts its stresses on the delicate lung tissue. Tidal volumes appear to be a critical variable in the causation of lung damage (Wheeler \& Bernard 2007). In conjunction with the high oxygen concentration required to keep a reasonable blood $\mathrm{PO}_{2}$, this can further damage the lung.

\subsection{Specific drug treatments in sepsis}

Many trials of anti-inflammatory chemotherapy have been held in septic shock, including against (Riederman, Guo, \& Ward 2003): immune regulation, endotoxin, TNFa, NO, IL-1, oxidants, neutrophil activity, complement, and coagulation. In practice, only steroid therapy and activated protein C (APC) have been validated as useful in improving survival. The reasons why the other therapeutic avenues have not proven successful include a) nonhomogeneity of the study populations, and b) the ill-understood multifactorial complexity of the sepsis syndromes. However, newer approaches to suppressing pro-inflammatory processes are being experimented with, such as anti-HMGB1 antibodies; these could suppress the late-acting pro-inflammatory cytokine High-Mobility Group Box-1 protein. It is know that this increases survival in the caecal puncture model of sepsis (van der Poll.T \& Opal 2008).

Steroid therapy has its known complications. APC acts as an anti-coagulant (thus important in DIC) as well as an inhibitor of production of IL-1, IL-6 and TNFa. The side effects are intracerebral (Recombinant human Protein C Worldwide Evaluation in Severe Sepsis (PROWESS) study group. 2001) and pulmonary haemorrhage (personal observations) (Fig 11). Another specific complication in modern chemotherapy is the increased susceptibility to certain pathogens with immunodulatory drugs. An example is the negative impact of adalimumab if the patient has tuberculosis as a co-morbidity (Lever \& Mackenzie 2007).

The known increase in apoptosis in the lymphoid population (Hotchkiss, Swanson, Freeman, \& et al 1999) has prompted consideration of anti-apoptotic chemotherapy. However, the potential of uncontrolled cell growth has to be evaluated first. 


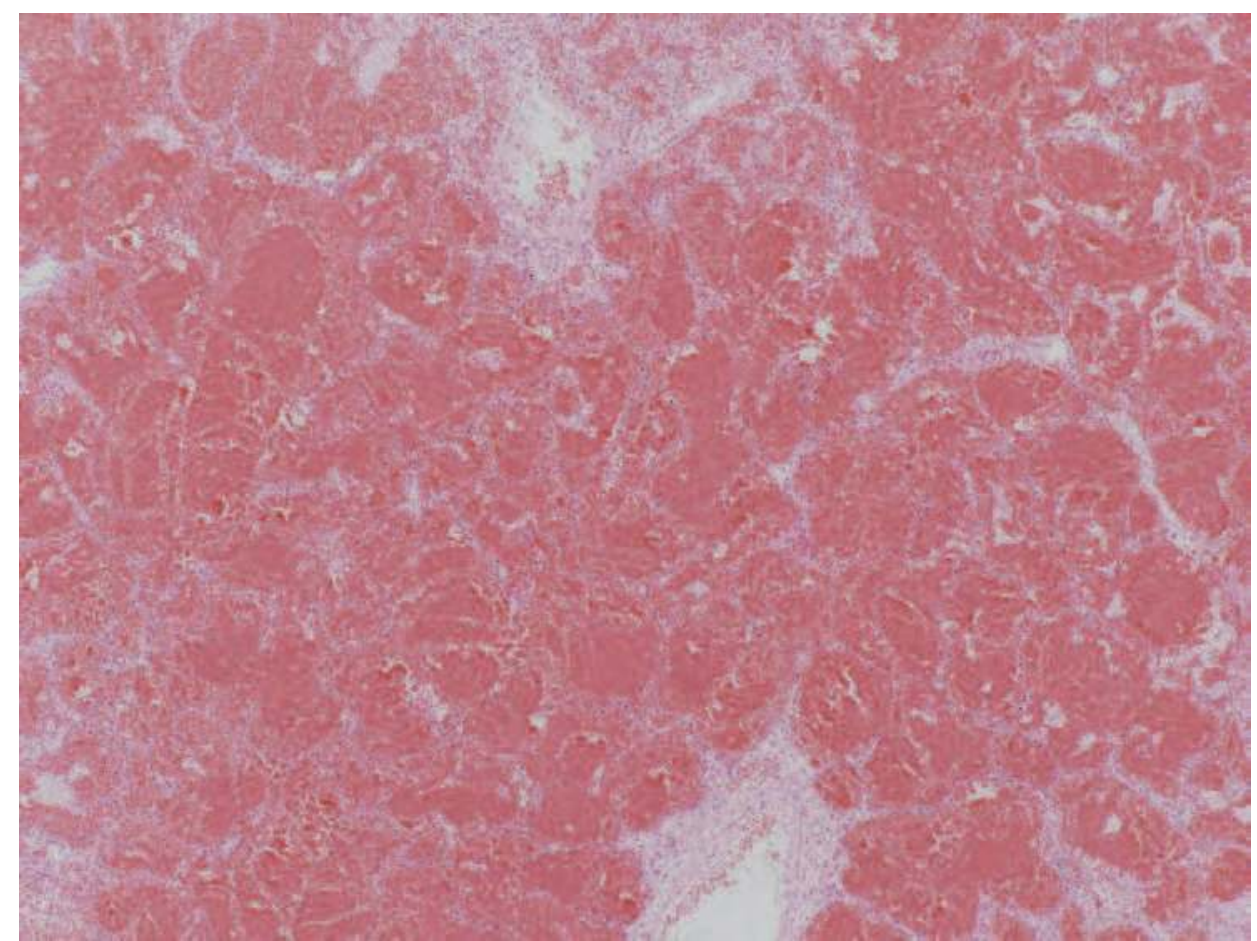

Fig. 11. Lung with massive haemorrhage, associated with administration of activated protein $\mathrm{C}$ in a patient with sepsis (H\&E)

An epidemiological analysis of outcomes in cardiovascular disease patients demonstrated that statin therapy was associated with reduced rates of sepsis and fatality from sepsis (Hackam et al. 2006). As well as being lipid-lowering agents, statins have many other effects: anti-inflammatory, modulation of cellular immunity, improvement of endothelial cell function, and increasing the bio-availability of NO. Apart from suggesting further strategies in sepsis therapy, this observation reminds pathologists to look at the treatments patients are on when they undergo autopsy.

\section{Conclusion}

This brief review of septic shock autopsy pathology and its differential diagnosis has focussed on the major conditions. There are less obvious pathologies whose contribution to the disease and outcome are uncertain. For example, apoptosis of neurones and glial cells in the cardiovascular centres of the brain. Patients who died of septic shock showed more such apoptosis in the amygdala and medullary autonomic nuclei than those dying of non-septic shock and sudden extra-cranial trauma. This was strongly associated with endothelial iNOS expression (Sharshar et al. 2003). Does this significantly contribute to outcome over and above direct organ damage? 
In conclusion, there is much to be studied still in the morbid anatomy of sepsis syndromes. If pathologists are to be useful in sepsis research, careful documentation of autopsy organ pathology and microbiology, and the correlation of outcome with clinical features and the various therapeutic modalities, is essential. New treatments for severe sepsis are being trialled to raise the poor survival rates in intensive care. The role of the autopsy is thus threefold: to describe carefully the organ lesions and identify microbiological agents directly and through the particular host reactions (Table 5; Fig 12,13); to identify co-morbidities and complications of treatments; and to collaborate with clinicians in audit and improving the outcomes of septic patients.

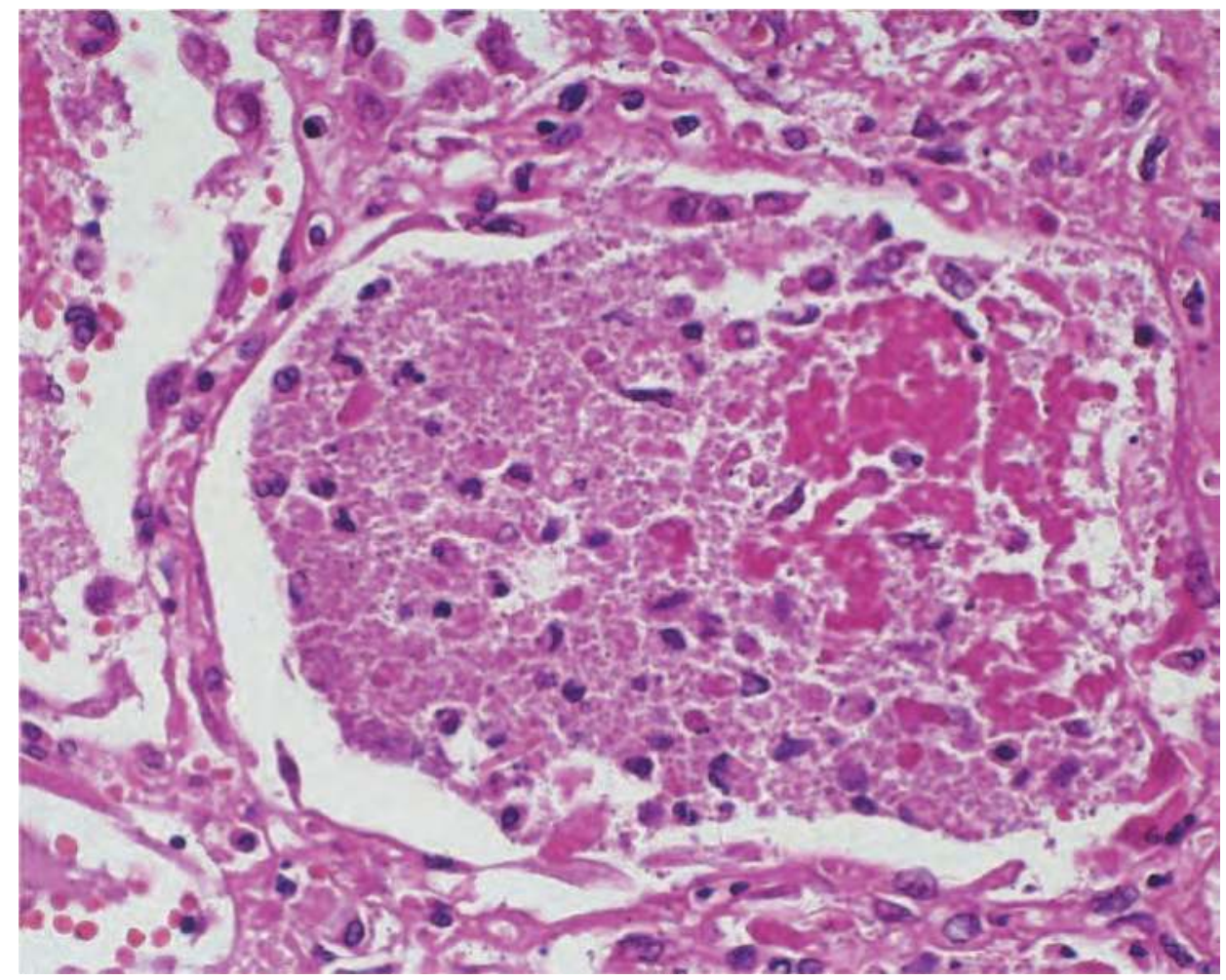

Fig. 12. Autopsy lung of an HIV+ve patient who died with lung and multi-organ failure of uncertain aetiology. The lung alveoli are filled with granular necrotic debris and minimal cellular reaction. This is non-reactive (anergic) tuberculosis infection - see Fig 13 (H\&E). 


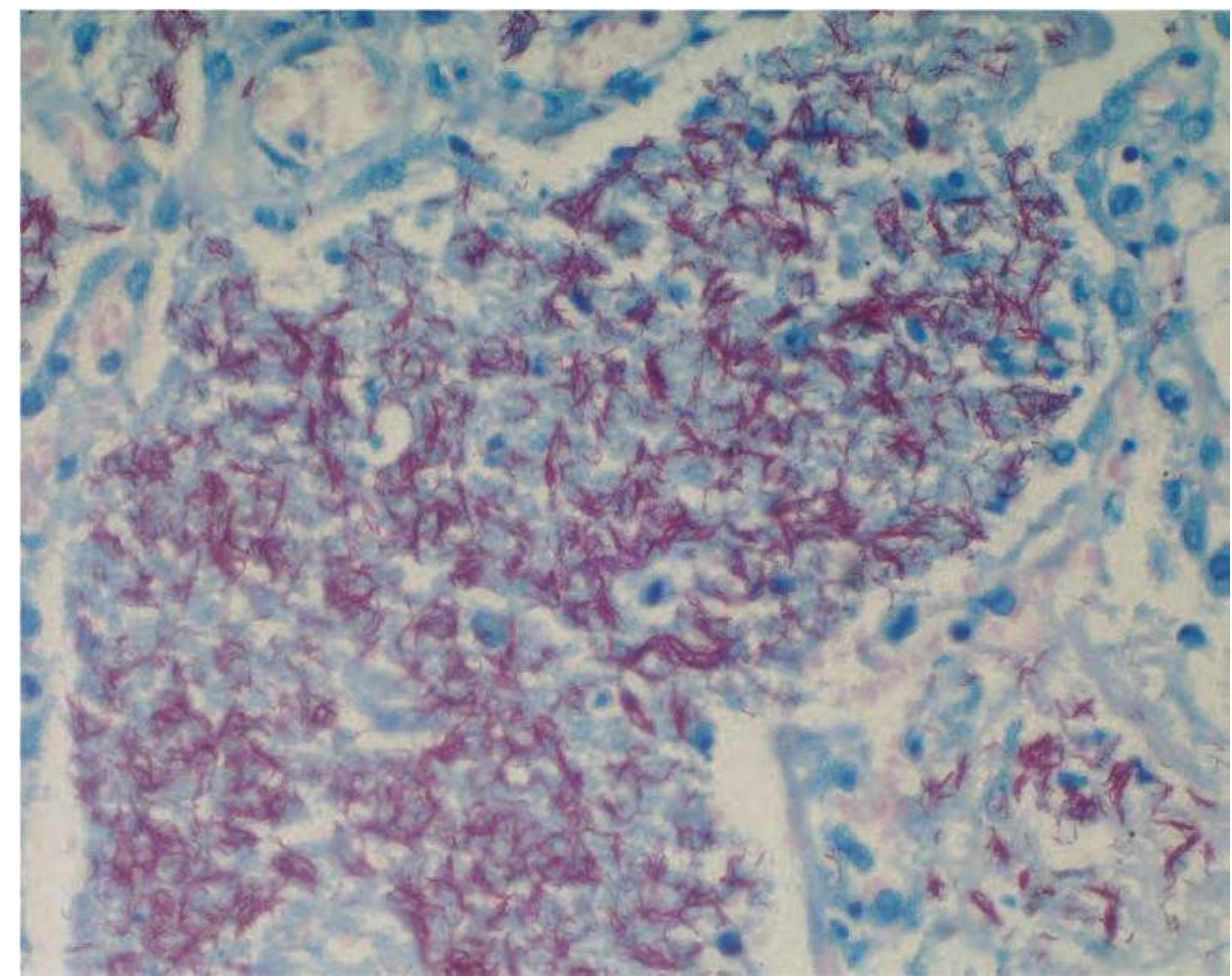

Fig. 13. Same lung as in Fig 12. The Ziehl-Neelsen stain reveals huge numbers of acid-fast bacilli. The 'granular debris' seen in Fig $12 \mathrm{H} \& \mathrm{E}$ stain is comprised of clumped bacilli.

\section{References}

Annane, D., Bellisant, E., \& Cavaillon, J.-M. 2005, "Septic shock", Lancet, vol. 365, pp. 63-78.

Arabi, Y., Ahmed, Q. A., Haddad, S., Aljumah, A., \& Al-Shimemeri, A. 2004, "Outcome predictors of cirrhosis patients admitted to the intensive care unit.", European Journal of Gastroenterology \& Hepatology, vol. 16, pp. 333-339.

Arismendi-Morrillo, G. J., Briceno-Garcia, A. E., Romero-Amaro, Z. R., \& et al 2004, "Acute non-specific splenitis as indicator of systemic infection. Assessment of 71 autopsy cases.", Invest.Clin., vol. 45, pp. 131-135.

Baroldi, G. 2006, "Basic pathophysiologic changes," in Pathology of the Heart and Sudden Death in Forensic Medicine, V. Fineschi, G. Baroldi, \& M. D. Silver, eds., CRC Press, Taylor \& Francis Group, Boca Raton, Fl, pp. 31-76.

Bisno, A. K. \& Stevens, D. L. 2005, "Streptococcus pyogenes," in Mandell, Douglas, and Bennett's Principles and Practice of Infectious Diseases, 6 edn, G. L. Mandell, J. E. Bennet, \& R. Dolin, eds., Elsevier Churchill Livingstone, Philadelphia, pp. 2362-2379.

Blosser, S. A., Zimmerman, H. E., \& Stauffer, J. L. 1998, "Do autopsies of critically ill patients reveal important findings that were clinical undetected?", Critical Care Medicine, vol. 26, pp. 1332-1336. 
Calandra, T., Cohen, J., \& et al 2005, "The International Sepsis Forum Consensus Conference on Definitions of Infection in the Intensive Care Unit.", Critical Care Medicine, vol. 33, pp. 1538-1548.

Christmas, A. B., Wilson, A. K., Franklin, G. A., \& et al 2005, "Cirrhosis and trauma: a deadly duo.", American Surgery, vol. 71, pp. 996-1000.

Combes, A., Mokhtari, M., Couvelard, A., \& et al 2004, "Clinical and autopsy diagnoses in the intensive care unit: a prospective study.", Archives of Internal Medicine, vol. 164, pp. 389-392.

Corley, D. E., Kirtland, S. H., Winterbauer, R. H., \& et al 1997, "Reproducibility of the histologic diagnosis of pneumonia among a panel of four pathologists.", Chest, vol. 112, pp. 458-465.

Corrin, B. \& Nicholson, A. G. 2011, "Diffuse alveolar damage," in Pathology of the Lung, 3 edn, B. Corrin \& A. G. Nicholson, eds., Churchill Livingstone, Elsevier, London, pp. 131149.

Danai, P. \& Martin, G. S. 2005, "Epidemiology of sepsis: recent advances.", Current Infectious Disease Reports, vol. 7, pp. 329-334.

Dellinger, P., Carlet, J. M., Masur, H., \& et al 2004, "Surviving Sepsis Campaign guidelines for management of severe sepsis and septic shock.", Critical Care Medicine, vol. 32, pp. 858-878.

Dellinger.R.P., Levy, M. M., Carlet, J. M., \& et al 2008, "Surviving sepsis campaign: international guidelines for management of severe sepsis and septic shock: 2008", Critical Care Medicine, vol. 36, pp. 296-327.

Di Sabatino, A., Carsetti, R., \& Corrazza, G. R. 2011, "Post-splenectomy and hyposplenic states.", Lancet, vol. 378, pp. 86-97.

Fisman, D. N. 2000, "Hemophagocytic syndromes and infection.", Emerging Infectious Diseases, vol. 6, pp. 601-608.

Fowler, A., Collins, L., de Ruiter, A., \& et al 2006, "Multicentric Castleman's disease in a patient with HIV.", International Journal of STD and AIDS, vol. 17, pp. 63-64.

Gildea, T. R., Cook, W. C., Nelson, D. R., \& et al 2004, "Predictors of long-term mortality in patients with cirrhosis of the liver admitted to a medical ICU.", Chest, vol. 126, pp. 1598-1603.

Goldman, L., Sayson, R., Robbins, S., Cohn, L. H., Bettman, M., \& Weisberg, M. 1983, "The value of the autopsy in three medical eras.", New England Journal of Medicine, vol. 308, pp. 1000-1005.

Ha, T., Grant, D., Xia, Y., \& et al 2006, "Glucan phosphate attenuates cardiac dysfunction and inhibits cardiac MIF expression and apoptosis in septic mice.", American Journal of Physiology Heart Circulatory Physiology, vol. 291, p. H1910-H1918.

Hackam, D. G., Mamdani, M., Li, P., \& Redelmeier, D. A. 2006, "Statins in patients with cardiovascular disease: a population-based cohort analysis.", Lancet, vol. 367, pp. 413-418.

Hayashida, M., Shoujima, T., Teshima, H., \& et al 2004, "Clinical outcome after cardiac operations in patients with cirrhosis.", Annals of Thoracic Surgery, vol. 77, pp. 500505.

Hirata, K., Miyagi, S., Tome, M., \& et al 1988, "Cor pulmonale due to tumour cell microemboli.", Archives of Internal Medicine, vol. 148, pp. 2287-2289. 
Hosler, G. A., Cusumano, A. M., \& Hutchins, G. M. 2003, "Thrombotic thrombocytopenia purpura and hemolytic uremic syndrome are distinct pathologic entities. A review of 56 autopsy cases.", Archives of Pathology and Laboratory Medicine, vol. 127, pp. 834839.

Hotchkiss, R. S., Swanson, P. E., Freeman, B., \& et al 1999, "Apoptotic cell death in patients with sepsis, shock, and multiple organ dysfunction.", Critical Care Medicine, vol. 27, pp. 1230-1251.

Lever, A. \& Mackenzie, I. 2007, "Sepsis: definition, epidemiology, and diagnosis", Bmj, vol. 335, pp. 879-883.

Levy, M. M. \& et al 1992, "SCCM/ESICM/ACCP/ATS/SIS International Sepsis Definitions Conference.", Critical Care Medicine, vol. 31, pp. 1250-1256.

Levy, R. J., Piel, D. A., ACton, P. D., \& et al 2005, "Evidence of myocardial hibernation in the septis subject.", Critical Care Medicine, vol. 33, pp. 2752-2756.

Lucas, S. B. 2007, "The autopsy pathology of sepsis-related death", Current Diagnostic Pathology, vol. 13, pp. 375-388.

Lucas, S. B. 2011, "Saving Mothers' Lives: Sepsis in pregnancy. Annex 7.1. A possible future approach to case definitions.", British Journal of Obstetrics and Gynaecology, vol. 118, no. supplement 1, March 2011, pp. 97-101.

Mitchell, R. N. 2005, "Hemodynamic disorders, Thromboembolic disease, and Shock.," in Robbins and Contran Pathologic Basis of Disease, 7 edn, V. Kumar, A. K. Abbas, \& N. Fausto, eds., Elsevier Saunders, Philadelphia, pp. 119-144.

Moreillon, P., Que, Y.-A., \& Glauser, M. P. 2005, "Staphylococcus aureus (including staphylococcal toxic shock)," in Mandell, Douglas, and Bennett's Principles and Practice of Infectious Diseases, 6 edn, G. L. Mandell, J. E. Bennet, \& R. Dolin, eds., Elsevier Churchill Livingstone, Philadelphia, pp. 2321-2351.

Morris, A., Masur, H., \& Huang, L. 2006, "Current issues in critical care of the HIV-infected patient.", Critical Care Medicine, vol. 34, pp. 42-49.

Morris, J. A., Harrison, L. M., \& Partridge, S. M. 2006, "Postmortem bacteriology: a reevaluation", Journal of Clinical Pathology, vol. 59, no. 1, p. 9.

Munford, R. S. 2005, "Sepsis, severe sepsis, and septic shock," in Mandell, Douglas and Bennett's Principles and Practice of Infectious Diseases, 6 edn, G. L. Mandell, J. E. Bennet, \& R. Dolin, eds., Elsevier Churchill Livingstone, Pennsylvania, pp. 906-925.

National Confidential Enquiry into Patient Outcome and Death 2006, The Coroner's Autopsy: Do we deserve better? www.ncepod.org.uk.

Ningsanond, V. 2000, "Infection associated hemophagocytic syndrome: a report of 50 children.", Journal of the Medical Association of Thailand, vol. 83, pp. 1141-1149.

Nishida, N., Chiba, T., Ohtani, K., Ikeda, N., Katayama, Y., \& Yoshioka, N. 2006, "Relationship between cardiopulmonary resuscitation and injuries of the cardiac conduction system: pathological features and pathogenesis of such injuries.", Critical Care Medicine, vol. 34, pp. 363-367.

Perkins, G. D., McAuley, D. F., Davies, S., \& Gao, F. 2003, "Discrepancies between clinical and postmortem diagnoses in critically ill patients: an observationsl study.", Critical Care, vol. 7, p. R129-R132.

Racusen, L. \& Kashgarian, M. 2007, "Ischemic and toxic acute tubular damage and other ischemic renal injury.," in Heptinstall's Pathology of the Kidney, 6 edn, J. C. Jennette et al., eds., Lippincott, Williams \& Wilkins, Philadelphia, pp. 1139-1186. 
Recombinant human Protein C Worldwide Evaluation in Severe Sepsis (PROWESS) study group. 2001, "Efficacy and safety of recombinant human activated protein $C$ for severe sepsis.", New England Journal of Medicine, vol. 344, pp. 699-709.

Riederman, N. C., Guo, R.-F., \& Ward, P. A. 2003, "The enigma of sepsis.", Journal of Clinical Investigation, vol. 112, pp. 460-467.

Rockey, D. C. \& Bissell, M. 2006, "Non-invasive measures of liver fibrosis.", Hepatology, vol. 43, p. S113-S120.

Roosen, J., Frans, E., Wilmer, A., Knockaert, D. C., \& Bobbaers, H. 2000, "Comparison of premortem clinical diagnoses in critically ill patients and subsequent autopsy findings.", Mayo Clin Proc, vol. 75, pp. 562-567.

Royal College of Pathologists 2005, Sudden death with likely cardiac pathology www.rcpath.org.

Scheuer, P. \& Lefkowitch, J. H. 2006, "The liver in systemic disease and pregnancy," in Liver Biopsy Interpretation, 7 edn, Elsevier Saunders, pp. 331-332.

Schnadig, V. J., Molina, C. P., \& Aronson, J. F. 2007, "Cytodiagnosis in the autopsy suite: a tool for improving autopsy quality and resident education.", Arch Pathol Lab Med, vol. 131, pp. 1056-1062.

Sharshar, T., Gray, F., de la Grandmaison, G. L., \& et al 2003, "Apoptosis of neurons in cardiovascular autonomic centres triggered by inducible nitric oxide after death from septic shock.", Lancet, vol. 362, pp. 1799-1805.

Singer, M., De Santis, V., Vitale, D., \& Jeffcoate, W. 2004, "Multiorgan failure is an adaptive, endocrine-mediated, metabolic response to overwhelming systemic inflammation.", Lancet, vol. 364, pp. 545-548.

Stauss, R., Neureiter, D., Westenburger, B., \& et al 2004, "Multifactorial risk analysis of bone marrow histiocytic hyperplasia with hemophagocytosis in critically ill medical patients - a postmortem clinicopathologic analysis.", Critical Care Medicine, vol. 32, pp. 1316-1321.

Stebbing, J., Adams, C., Mletzko, S., \& et al 2011, "Plasma HHV8 DNA predicts relapse in individuals with HIV-associated multicentric Castleman disease.", Blood, vol. 118, pp. 271-275.

Takahashi, N., Chubachi, A., Kume, M., \& et al 2001, "A clinical analysis of 52 adult patients with hemophagocytic syndrome: the prognostic significance of the underlying diseases.", International Journal of Haematology, vol. 74, pp. 209-213.

Tissari, P., Zumla, A., Tarkka, E., \& et al 2010, "Accurate and rapid identificatino of bacterial species from positive blood cultures with a DNA-based microarray platform: an observational study.", Lancet, vol. 375, pp. 224-230.

Toh, C. H. \& Dennis, M. 2003, "Disseminated intravascular coagulation: old disease, new hope", British Medical Journal, vol. 327, pp. 974-977.

Tsokos, M. 2003, "Immunohistochemical detection of sepsis-induced lung injury in human autopsy material.", Legal Medicine, vol. 5, pp. 73-86.

van der Poll.T \& Opal, S. M. 2008, "Host-pathogen interactions in sepsis.", Lancet Infectious Diseases, vol. 8, pp. 32-43.

Villar, J., Maca-Meyer, N., Perez-Mendez, L., \& Flores, C. 2004, "Bench-to-bedside review: understanding genetic predisposition to sepsis.", Critical Care, vol. 8, pp. 180-189.

Vincent, J. L. \& Singer, M. 2010, "Critical care: advances and future prospects", Lancet, vol. 376, pp. 1354-1361. 
Wheeler, A. P. \& Bernard, G. R. 2007, "Acute lung injury and teh acute respiratory distress syndrome: a clinical review", Lancet, vol. 369, pp. 1553-1565.

Whitwell, H. 2005, "Techniques.," in Forensic Neuropathology, H. Whitwell, ed., Hodder Arnold, London, pp. 20-35.

Zhu, B. L., Ishikawa, T., Michiue, T., Quan, L., \& Maeda, H. 2005, "Postmortem serum endotoxin level in reiation to the causes of death.", Legal Medicine, vol. 7, pp. 103109. 


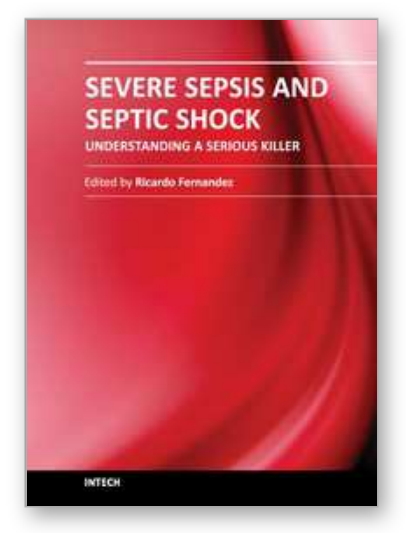

\author{
Severe Sepsis and Septic Shock - Understanding a Serious Killer \\ Edited by Dr Ricardo Fernandez
}

ISBN 978-953-307-950-9

Hard cover, 436 pages

Publisher InTech

Published online 10, February, 2012

Published in print edition February, 2012

Despite recent advances in the management of severe sepsis and septic shock, this condition continues to be the leading cause of death worldwide. Some experts usually consider sepsis as one of the most challenging syndromes because of its multiple presentations and the variety of its complications. Various investigators from all over the world got their chance in this book to provide important information regarding this deadly disease. We hope that the efforts of these investigators will result in a useful way to continue with intense work and interest for the care of our patients.

\title{
How to reference
}

In order to correctly reference this scholarly work, feel free to copy and paste the following:

Sebastian Lucas (2012). The Autopsy Pathology of Sepsis-Related Death, Severe Sepsis and Septic Shock Understanding a Serious Killer, Dr Ricardo Fernandez (Ed.), ISBN: 978-953-307-950-9, InTech, Available from: http://www.intechopen.com/books/severe-sepsis-and-septic-shock-understanding-a-serious-killer/theautopsy-pathology-of-sepsis-and-septic-shock

\section{INTECH}

open science | open minds

\section{InTech Europe}

University Campus STeP Ri

Slavka Krautzeka 83/A

51000 Rijeka, Croatia

Phone: +385 (51) 770447

Fax: +385 (51) 686166

www.intechopen.com

\section{InTech China}

Unit 405, Office Block, Hotel Equatorial Shanghai

No.65, Yan An Road (West), Shanghai, 200040, China

中国上海市延安西路 65 号上海国际贵都大饭店办公楼 405 单元

Phone: +86-21-62489820

Fax: +86-21-62489821 
(C) 2012 The Author(s). Licensee IntechOpen. This is an open access article distributed under the terms of the Creative Commons Attribution 3.0 License, which permits unrestricted use, distribution, and reproduction in any medium, provided the original work is properly cited. 